\title{
Measuring Judicial Ideal Points in New Democracies: The Case of the Philippines
}

\author{
Lucia DALLA PELLEGRINA* \\ Assistant Professor, Bocconi University, Milan
}

Laarni ESCRESA**

Post-doctoral Fellow, European University Institute, Florence

Nuno GAROUPA***

Professor of Law and H. Ross and Helen Workman Research Scholar, University of Illinois

\begin{abstract}
This paper extends the empirical analysis on the determinants of judicial behaviour by measuring the ideal points for the Justices of the Philippine Supreme Court for 1986-2010. The Philippines is an interesting case given the US influence in designing the Supreme Court while the political and social context differs significantly. The estimated ideal points allow us to focus on political coalitions based on presidential appointments. We find strong evidence to support the existence of such coalitions along a government-opposition policy space. Implications for comparative judicial politics are discussed.
\end{abstract}

Keywords: constitutional court, constitutional review, empirical analysis, ideal point, the Philippines

\section{INTRODUCTION}

In the field of comparative judicial politics, the Philippines present a particularly relevant case. Given the contemporary history of the Philippines, the Supreme Court has many similarities to the US Supreme Court since the general design was transplanted in the early twentieth century. ${ }^{1}$ However, there are some important practical differences. They largely

- We have benefited from the stimulating comments provided by one anonymous referee. We are grateful to Purple Romero for superb research assistantship. We are also grateful to Roya H. Samarghandi for reviewing the paper. The usual disclaimers apply.

* Assistant Professor, Bocconi University, Milan (PhD Economics, Bocconi University)

** Post Doctoral Fellow, European University Institute, Florence (PhD Law and Economics, European Doctoral Program in Law and Economics, University of Bologna)

*** Professor of Law and H. Ross and Helen Workman Research Scholar, University of Illinois (PhD Economics, University of York)

1. The Philippines was a Spanish colony until the Spanish-American War (1898). American sovereignty over the Philippines was recognized by the Treaty of Paris (December 1898). For the period 1901-35, the Philippines was under American influence and subject to governmental charters. It evolved into a commonwealth of the United States in the period 1935-46 (although under Japanese occupation during World War II). The Second Republic (1946-65) secured the independence of the Philippines but was dominated by ineffective and increasingly corrupt administrations. 
result from not only the variety of institutional arrangements, but also the local economic and social context.

There have been significant advances in the empirical study of Asian courts, including the Philippines, in recent decades. ${ }^{2}$ In this paper, however, we address judicial behaviour in the Filipino Supreme Court with a different empirical methodology. We estimate individual ideal points for each Justice during the period 1986-2010. The American empirical literature on the behaviour of the Supreme Court Justices developed a sophisticated method for estimating individual judges' ideal points based on how judges manifest their views in dissenting and concurring opinions. ${ }^{3}$ Technically, the empirical method of estimation revealed those points in some $n$-dimensional space of politically relevant choices, which judges prefer over all other points in that space. Utilizing this particular approach allows us to estimate judicial ideal points by ranking them in one dimension. Essentially, we treat each presidential term as a single large court for which, based upon how the Justices have voted, we estimate their individual ideal points.

In the context of the US Supreme Court, it has been shown that the ideal points of individual Justices can be consistently estimated in a one-dimensional space that reflects the traditional conservative-liberal dichotomy. Although results suggest that US Supreme Court Justices do not have temporally constant ideal points, they seem to correlate quite significantly with the general perception of which Justices are conservative or liberal. Therefore, ideal point estimations are still viewed as a rightful measurement to predict judicial behaviour.

Our paper develops a similar exercise for the Supreme Court of the Philippines. Considering the peculiarities of the Philippine case, the relevant policy space is along a government-opposition divide (since the traditional conservative-liberal dichotomy is not persuasive in the Filipino context). ${ }^{4}$ The unique dataset was collected by the authors and includes 125 decisions from 1986 to 2010 . Historically, we consider four presidential terms following the EDSA revolution (or the "people power revolution") that led to the downfall of Ferdinand Marcos and the return to democracy in 1986, namely Corazón Aquino (1986-92), Fidel Ramos (1992-98), Joseph Estrada (1998-2001), and Gloria Arroyo (2001-10). All Presidents have faced serious political challenges after the restoration of democracy. Among them were issues that stemmed from a politicized military and moves to amend the Constitution to abolish term limits.

The Supreme Court has played a significant political role since its foundation and has been involved in critical constitutional review with considerable policy consequences. Apparently, the Court enjoyed a reputation for independence before the Marcos dictatorship (1972-86). ${ }^{5}$ Due to the fact that the Court was largely perceived as subservient to President

\section{(F'note continued)}

President Marcos was elected democratically in 1965 in the context of a difficult political struggle, but declared martial law in 1972, thus inaugurating a period of authoritarian government.

2. On Asian courts, see Ginsburg (2003); Ramseyer \& Rasmusen (2003, 2006); Garoupa et al. (2011); Dalla Pellegrina et al. (2012). On the Philippines, see Tate (1993); Tate \& Haynie (1993, 1994); Smith \& Farrales (2010); and Escresa \& Garoupa $(2012,2013)$.

3. See mainly Martin \& Quinn (2002), as well as Jackman (2001); Bafumi et al. (2005); Peress (2009); Wetstein et al. (2009); Hanretty (2012); and Dalla Pellegrina et al., supra note 2.

4. This, however, does not suggest the absence of any ideological divisions within the Court (or other policy space to characterize judicial preferences), as illustrated by the Supreme Court Oral Arguments held from 9 July to 27 August 2013, concerning the constitutionality of the Reproductive Health Law that was enacted under B. Aquino.

5. See Tate \& Haynie, supra note 2. 
Marcos and unpopular, the Court was purged in 1986 and repopulated by the new democratic regime. President Aquino accepted the resignation of all Justices and appointed the entire Court according to her preferences and political needs (in fact, reappointing those Justices perceived to be less likely to oppose her). Sixty-six Justices have served between 1986 and 2010. The 1987 Constitution contained provisions aimed at preventing the return of authoritarian rule in the country. With respect to the Supreme Court, this includes the expansion of the scope of judicial review, ${ }^{6}$ its rule-making powers, and the creation of a Judicial and Bar Council to guarantee its independence.

The general perception is that the Court is too deferential to the President in office, occasionally corrupt, and highly politicized. ${ }^{7}$ Several famous cases have raised concerns about the independence of the Philippine Supreme Court. ${ }^{8}$ There is a general sense that the members of the Court defer regularly to the appointer and are unable to disregard the immediate interests of the President. As a consequence, the Supreme Court faces serious criticism regularly. ${ }^{9}$

In a previous paper, some of the authors have studied the correlation between votes in the Supreme Court and presidential appointees. ${ }^{10}$ Our results show an important alignment between individual Justices and the interests of the presidential appointers, although it varies across presidential terms. We argued that, although our dataset reflects the most politically salient cases, there is a significant proportion of anti-administration votes, which is surprising given the usual account by local experts.

In a second paper, the same authors have applied the strategic defection model to the Philippine context. ${ }^{11}$ This model, based on the assumption that judges are politically dependent, argues for a concentration of anti-administration votes at the end of each presidential term, in particular, if they reflect a significant change of political majorities. The empirical results do not offer strong support to the model. However, there could be contextual particularities with the changes in administration in 1992, 1998, 2001, and 2010 that might explain the problems with the strategic defection model in the Philippines.

In this paper, we turn our attention to judicial ideal points. In tune with research on the US Supreme Court, our results show that judicial ideal points follow closely coalitions polarized by presidential appointments. Therefore, our results generally support our previous findings. The Supreme Court is largely polarized along presidential influence. It does not seem significantly different from the US Supreme Court, although for possibly different reasons.

Our paper makes three important contributions to the growing comparative empirical studies. First, it estimates judicial ideal points outside the US court system. Second, it compares the Filipino and the American Supreme Courts. Third, it provides an empirically oriented framework for future research on judicial politics in the Philippines and other countries with similar histories of authoritarian rule and restored democracies.

6. Many cases were non-justiciable before under the political question doctrine. This was frequently used by the Court during the Marcos period to decline review and avoid politically cumbersome cases. The political question doctrine in the Philippines was inspired by the US doctrine of the same name.

7. See Vitug (2010).

8. See "Appendix A" for a list of some of the landmark cases.

9. See Vitug, supra note 7.

10. See Escresa \& Garoupa (2012), supra note 2.

11. See Escresa \& Garoupa (2013), supra note 2. 
Table 1. Judicial appointments, 1986-2010

\begin{tabular}{lccccc}
\hline President & $\begin{array}{c}\text { Number of } \\
\text { appointees }\end{array}$ & $\begin{array}{c}\text { Percentage } \\
\text { male }\end{array}$ & $\begin{array}{c}\text { Percentage } \\
\text { judicial } \\
\text { experience }\end{array}$ & $\begin{array}{c}\text { Percentage } \\
\text { law } \\
\text { professor }\end{array}$ & $\begin{array}{c}\text { Percentage } \\
\text { public } \\
\text { official }\end{array}$ \\
\hline Marcos* (1965-86) & 5 & $80 \%$ & $80 \%$ & $40 \%$ & $100 \%$ \\
C. Aquino (1986-92) & 19 & $84 \%$ & $37 \%$ & $84 \%$ & $47 \%$ \\
Ramos (1992-98) & 14 & $100 \%$ & $79 \%$ & $86 \%$ & $71 \%$ \\
Estrada (1998-2001) & 6 & $50 \%$ & $100 \%$ & $50 \%$ & $67 \%$ \\
Arroyo (2001-10) & 21 & $81 \%$ & $71 \%$ & $67 \%$ & $52 \%$ \\
$\begin{array}{l}\text { B. Aquino (June- } \\
\text { December 2010) }\end{array}$ & 1 & $0 \%$ & $0 \%$ & $100 \%$ & $0 \%$ \\
TOTAL & 66 & $82 \%$ & $65 \%$ & $73 \%$ & $59 \%$ \\
\hline
\end{tabular}

*The five justices appointed by Marcos were reappointed and served under C. Aquino.

In Section 2, we address the case of the Philippines. In Section 3, we develop a theoretical framework to explain judicial ideal points. In Section 4, we present our empirical results. And finally, in Section 5, we conclude this paper.

\section{THE CASE OF THE PHILIPPINES ${ }^{12}$}

The Supreme Court of the Philippines is composed of 15 Justices appointed by the President. The Chief Justice is also picked by the President, although there is an informal rule that the longest-serving Justice should be picked. Presidents have broken this rule periodically. ${ }^{13}$ Justices are appointed for life, subject to mandatory retirement at age 70 . They can be removed from office through impeachment or resignation. Table 1 summarizes the composition of the Supreme Court between 1986 and 2010.

There were 66 Justices appointed to the Supreme Court during the period considered. The average length of tenure is six and a half years. Most served their full term. Four justices resigned before reaching the age of retirement. ${ }^{14}$ In 2012, Chief Justice Renato Corona was the first Justice to be impeached and convicted in the country's history. The lowest percentage of Justices appointed with no judicial experience happened under the Aquino government, which is consistent with her establishment of a revolutionary government (we ignore for the purpose of comparative description the Justices appointed so far by President Benigno Aquino III). On the other hand, the highest percentage of appointments with judicial experience occurred under Estrada. ${ }^{15}$

According to the Philippine 1987 Constitution, the Supreme Court is supposed to settle controversies and to determine if there is abuse of power by the government. The Court

12. This section largely follows Escresa \& Garoupa (2012), supra note 2.

13. For example, in 2005, when President Arroyo appointed Artemio Panganiban Chief Justice rather than Reynato Puno and in 2010, when she picked Renato Corona rather than Antonio Carpio. More recently, President Aquino appointed Maria Lourdes Serenio Chief Justice, the most junior candidate.

14. The reasons for resignation vary. Former Chief Justice Marcelo Fernan ran as Vice-President. Justice Florentino Feliciano was appointed to the Appellate Body of the World Trade Organization. Justice Hugo Gutierrez resigned following allegations concerning the authenticity of his authorship of a decision that favoured the monopoly power of a telecommunications company. Justice Alicia Austria Martinez cited health reasons.

15. A detailed study of judicial appointments to the Court is provided by Gatmaytan \& Magno (2011). The authors show that nominees and appointees all have similar backgrounds and are unrepresentative of modern Philippine society. 
currently operates by three divisions of five Justices each, although other possibilities are contemplated in the Constitution. Separate opinions are allowed but a concurrence of the majority is needed to settle a case. The most important and relevant cases are decided en banc. ${ }^{16}$

In order to understand the dynamics of court behaviour and judicial review in the Philippines, we briefly provide an overview of the key events that happened and situate the role of the judiciary in this development. More than two decades after the end of the Marcos dictatorship, the Philippines experienced another people's uprising that led to the ousting of President Estrada, ${ }^{17}$ an impeachment trial of the President, ${ }^{18}$ eight coup attempts, ${ }^{19}$ and moves to change the 1987 Constitution that would extend presidential term limits and change the form of government to a parliamentary system. ${ }^{20}$

These events point out that the Philippines is not yet a stable democracy. Rather, it could be more appropriately characterized as undergoing the process of institutional experimentation towards a mature and working democracy. Thus, in the Philippine case, the Supreme Court, aside from performing its usual functions, has also played crucial roles in shaping the democratic and institutional set-up that eventually emerged. These are displayed in several circumstances. ${ }^{21}$

The crucial role that the Supreme Court has assumed over the past two decades, has paved the proper incentives for the incumbent administration to exercise influence and control over it. One way is through the appointment stage. It is in the interest of the President to appoint a judge who shares his policy preferences.

Changes at the end of political cycles have not been easy in the Philippines. The 1987 Constitution established one term of six years with no possibility of re-election. President "Cory Aquino" came to power through the "people power revolution." It resulted from a series of events, namely massive electoral fraud and a coup attempt by a faction of the military that culminated in the people pouring on to the streets and her being sworn into office by a Justice of the Supreme Court, Claudio Teehankee, who later became the Chief Justice. She left office in 1992 , at the end of her term, although her administration was rocked by coup attempts. ${ }^{22}$

16. See "Appendix B" for the list of cases decided en banc.

17. On 17-20 January 2001, a peaceful people's uprising, known as People Power 2, took place after the impeachment trial of President Estrada was aborted. On the fourth day, the military withdrew their support for Estrada and the Supreme Court swore into office Vice-President Gloria Macapagal Arroyo as the President of the Republic; see Lande (2001).

18. An Impeachment Complaint was filed on 18 October 2000 at the House of Representatives accusing Estrada of bribery, graft, and corruption, abuse of public trust, and culpable violation of the Constitution, which are all impeachable offences under the 1987 Constitution, mainly for his involvement in an illegal lottery game; see Kasuya (2005).

19. Seven coups were staged against Aquino and one under Arroyo. This figure does not include the unsuccessful coup plots and attempts. The frequency of their occurrence can be traced to a politicized military whose influence in civilian affairs continued even after the end of the Marcos dictatorship; see Gloria (2003).

20. Except under Cory Aquino, all succeeding administrations introduced significant moves to amend the Constitution.

21. For example, at the height of the two people's uprisings or "people power," it timely swore into oath Aquino and Arroyo as the Presidents of the Philippines, immediately solving the issue of succession and legitimacy at the same time. Other important developments include: Chief Justice Hilario Davide presiding over the impeachment trial of Estrada when the Senate convened itself into an impeachment court; under Chief Justice Reynato Puno, the Court exercising its rule-making powers by promulgating the Rules on the Writ of Amparo and the Writ of Habeas Data in response to the extra-judicial killings and involuntary disappearances of journalists, leaders, and members of the left and progressive movement during the Arroyo government; the Court deciding on constitutional and key issues that involve the term extension or survival of the incumbent President (this happened under the Ramos's administration in 1997 in Santiago v. Comelec and under Arroyo's administration in 2006 in Lambino v. Comelec).

22. Cory Aquino announced in advance she had no intention of serving another term even as her supporters wanted her to. 
President Ramos started his term in 1992, a term characterized by a period of relative stability. Ramos, one of the key generals who withdrew his support for Marcos and who remained loyal to Aquino, ruled by consensus and introduced the so-called "Rainbow coalition," an alliance of parties from different political spectrums in the legislature. The most controversial ruling in his term involved the Supreme Court's rejection of the introduction of constitutional amendments to extend presidential term limits (PIRMA) that would have benefited Ramos directly.

Estrada won by an overwhelming majority against the candidate supported by Ramos. Unlike Ramos, who only won by a plurality of votes and needed consensus, Estrada implemented his legislative agenda without proper consideration of other political parties, in particular, the coalition that had supported Aquino and Ramos. Later, he was accused of grand corruption involving his participation in an illegal lottery game. An impeachment trial started in the Senate and when the majority of Senators allied with Estrada voted to suppress a key piece of evidence in the Court, the people flocked on to the streets. It was followed by the withdrawal of support by the military. ${ }^{23}$ The Supreme Court Chief Justice swore into office Vice-President Macapagal Arroyo (from the coalition supported by Ramos) at the height of the demonstrations. ${ }^{24}$ The Supreme Court played a distinct role in the transfer of power in 2001.

In contrast to Estrada, President Arroyo promised a more transparent and clean government. Her popularity began to dip when corruption scandals started erupting involving the first family. After her first term ended in 2004, she reversed an earlier proclamation that she would not seek a second term. She won by a slim margin. Evidence of massive electoral fraud led to events that resembled the making of another people power and a military coup. However, this was pre-empted by a timely declaration of emergency rule. Her second term ended in 2010 and her candidate lost to Benigno Aquino III.

Arroyo appointed three Chief Justices and ignored the tradition of appointing the most senior twice. She bypassed Reynato Puno for Artemio Panganiban in 2005 and bypassed Antonio Carpio for Renato Corona in 2010. The constitutionality of Corona's appointment was questioned before the Supreme Court in the light of a 60-day constitutional ban on presidential appointments before elections. It ruled that the Supreme Court was not included in the ban. ${ }^{25}$ Corona was later impeached in the second year of the B. Aquino administration. Although he was convicted for failing to declare his true assets and net worth, another ground for impeachment was his "partiality and subservience in cases involving the Arroyo administration." ${ }^{26}$ B. Aquino appointed Maria Lourdes Sereno as the new Chief Justice, who was also his first appointee to the Court. ${ }^{27}$

\footnotetext{
23. See Kasuya, supra note 18.

24. See G.R. No. 146738 Estrada v. Arroyo.

25. See G.R.No. 191002 .

26. There were eight Articles of Impeachment. The Senate, sitting as an impeachment court, found him guilty of the second article, which concerns his failure to publicly disclose his assets and liabilities as required by the Constitution.

27. The impeachment and conviction of Corona is the culmination of events reflecting the struggle between the former Chief Justice Corona, who was appointed by Arroyo and President B. Aquino. It began when B. Aquino chose to take his oath not from the Chief Justice, as accorded by tradition. The Supreme Court junked his two first Executive Orders. The Supreme Court issued a Temporary Restraining Order on 15 November 2011, forbidding the enforcement of DOJ Department Circular No. 41 and Watchlist Order Nos. ASM-11-237, 2011-422, 2011-573, allowing Gloria Arroyo to travel abroad. The Pampanga representative and former President faces a slew of criminal cases for her alleged involvement in corrupt transactions; see G.R. Nos. 199034 \& 199046.
} 


\section{THE RELEVANT POLICY SPACE IN THE PHILIPPINES}

\subsection{Strategic Voting}

The process of ideal point estimation generally seeks to map the policy preferences of Justices along a particular scale (Martin \& Quinn, 2002). An important question that needs to be addressed in estimating the ideal points of Justices in the Philippines is identifying the relevant and salient policy space to map the Justices' preferences. In the US, this usually takes the liberal-conservative continuum, which to a large extent reflects the ideological differences between the two relevant political parties and its particular institutional characteristics. In the case of the UK, where strategic behaviour is more frequently observed in the Parliament, Spirling and Mclean (2007) contend that a metric that shows a governmentopposition divide is more appropriate than one based on ideology. ${ }^{28}$

In countries where democratic institutions are weak and the executive enjoys a relative monopoly over the distribution of the political resource, the scope for strategic behaviour on the part of legislators and Justices may be wider. Under such conditions, the government-opposition divide becomes more appropriate (Zucco, 2009; Zucco \& Lauderdale, 2011). In Brazil, Zucco (2009) found that the concentration of political power on the incumbent President undermined the logic of party voting and encouraged patronage relationships. In order to distinguish the effect of presidential inducements from ideological voting, Zucco and Lauderdale (2011) used a hierarchical model and found the government-opposition dimension to be relevant.

The Philippines has a presidential system patterned after the US that, due to weak institutions, actually provides more powers to the President and is often described as a case of hyper-presidentialism (Rose-Ackerman et al., 2011). It has a multiparty system where discipline is weak and where classification based on ideology or any programmatic platform, such as state intervention or a laissez-faire policy, is a very challenging exercise. ${ }^{29}$ Members can easily shift from one party to the other and coalitions among them are formed based on political convenience or exigencies. Political parties usually serve as vehicles for campaigning during elections where the personality of the candidates is emphasized more than their policy platform. Personality, personal characteristics, and patronage and clientelistic relationships assume a larger role in explaining policy outcomes than party affiliation.

Similarly, studies on the Philippine Supreme Court have likewise shown that Justices act based on a variety of motivations other than ideology. ${ }^{30}$ There are other factors that enter into the utility of the Justices, such as their career aspirations and interests within and outside the judiciary. Once appointed as Associate Justices, they may aspire to the position of Chief Justice, or seek higher offices outside the Court before or after they reach the mandatory age of retirement. Achieving these career aspirations may depend on their behaviour in the Court and their relationship with the incumbent. Former Chief Justice Marcelo Fernan, for instance, did not serve his complete term so that he could run for Vice-President in the 1992 elections. ${ }^{31}$ Other Justices were also appointed to various government positions after

\footnotetext{
28. See also Dewan \& Spirling (2011) and Hix et al. (2006).

29. See, for instance, Abinales \& Amoroso (2005).

30. See, for instance, Vitug, supra note 7.

31. He lost in his election bid to become the second-highest official in the land. He subsequently ran for and won the Senate and served as Senate President. Another Associate Justice, Dante Tinga, also sought an elective position after his retirement by running for mayor of Taguig.
} 
they retired. Two former Chief Justices were subsequently appointed as Ambassadors to the United Nations. ${ }^{32}$ Associate Justices Jose Melo and Conchita Carpio-Morales were appointed as Chair of the Commission on Elections, and Ombudsman, respectively.

\subsection{President-Judge Ideal Points at the Appointment Stage}

Since the Justices are appointed by the incumbent President, what appears more salient is the relationship between the appointer and the appointee and the distance in their ideal policy preferences.

The choice of the distance in the ideal point for the Philippines is also grounded in the separation of powers theory. As the three branches of government are constitutionally endowed with sufficient powers to check excesses, and hence constrain each other, there are incentives for both the President and the Judges to behave strategically, in consideration and in anticipation of the moves of other branches of government. Moraski and Shipan (1999) showed how this is played out at the nomination and appointment stage in the US Supreme Court. Due to the crucial role of the Court in policy-making, it is in the interests of the President to appoint Justices whose ideal points are closest to him in order to bring the Court closer to his policy preferences. However, the nomination and selection process that requires Senate confirmation constrain him from doing so. In this case, the objective of the President is to minimize the distance between his and the Justice's ideal point subject to the constraint that the Senate find his nominee acceptable and avoid rejection. Moraski and Shipan (1999) identified the conditions under which these institutional constraints would be present depending on the composition of the Senate and of the Court. Shipan and Shannon (2003) showed that the same set of constraints also explains the length of Senate confirmation of United States Supreme Court Justices.

The process of judicial selection and appointment in the Philippines begins with the Judicial and Bar Council, a body created by the 1987 Constitution to guarantee the Court's independence. Its main function is to screen candidates to the Supreme Court and the lower courts in order to ensure that only those who are competent, have integrity, and are independent are selected to the Court. Article 8, Section 9, states that "The Members of the Supreme Court and judges of lower courts shall be appointed by the President from a list of at least three nominees preferred by the Judicial and Bar Council for every vacancy. Such appointments need no confirmation." The Council is composed of the Chief Justice, the Secretary of Justice, and a representative of Congress as ex-officio members, and representatives of the Integrated Bar, a professor of law, a retired member of the Supreme Court, and a representative of the private sector as regular members. ${ }^{33}$ The regular members are appointed by the President. Given that there is no confirmation process and five of the Council members are presidential appointees, the President is relatively less constrained in appointing a judge that is close to his ideal point and who moves the Court towards his preference. Prior to the Council, the 1935 Constitution required Congressional confirmation of the presidential nominee. While there was a lack of transparency in this process, the 1973 Constitution provided the President with the sole authority to appoint justices, and that only encouraged the perpetuation of patronage politics in the Supreme Court.

32. Chief Justices Claudio Teehankee and Hilario Davide served as Ambassadors of the Philippines to the United Nations.

33. Art. 8, s. 8 . 
Apart from the formal rules, there are also existing informal rules that serve as constraints to the President. In the appointment of the Chief Justice, for instance, there is a traditional rule that the President should pick the most senior Justice provided by the Council, and refrain from exercising his discretion. This rule had been broken in the past by Arroyo, and recently by B. Aquino. While breaking the informal rule permits the President to appoint someone closest to his preferences, its implicit cost is the possible reaction from Court members when the President appoints a Chief Justice who lacks the support of the other Court members. Further, it also has an impact on the Court's reputation and legitimizing function in society.

Likewise, the power to adjust the President's ideal point with the Justices can also be exercised at the exit stage. Chief Justice Renato Corona, an Arroyo appointee, was impeached and removed from office under the term of B. Aquino. An impeachment complaint was also filed against Chief Justice Hilario Davide, a C. Aquino appointee during the term of Arroyo, but it did not progress. ${ }^{34}$ Resignation is also another alternative, such as when C. Aquino asked all members of the Marcos Court to resign in $1986 .^{35}$

To conclude, given the particular institutional characteristics of the Philippines that relate to (i) strategic voting among judges, and (ii) the constraints of the President in appointing Justices closest to his ideal point, the relevant and salient policy space to map Justices' ideal points is along a government-opposition dimension.

\section{THE DATA AND RESULTS}

We have analyzed and coded 125 decisions issued by Supreme Court of the Philippines from 1986 to 2010, of these, 122 are decided within the four administrations concerned. ${ }^{36}$ All cases were decided en banc. As discussed earlier, we included all cases that are political in nature. ${ }^{37}$ These decisions have obvious political content and therefore do not require secondguessing concerning the political interests involved (a larger dataset would be inevitably contaminated by less politicized cases that would require a more subjective assessment if a decision is favourable to the government). ${ }^{38}$

We followed the methodological approach of previous scholarship, which is based on item response theory (IRT). ${ }^{39}$ We let $x_{i j}$ be the vote of each Justice $j(j=1, \ldots, J)$ for decision

34. The move was initiated by Estrada's allies in Congress after he was ousted from power.

35. During the Marcos period in 1982, twelve Justices resigned following a bar examination scandal in which it was acknowledged that a Justice's son's grade was changed to pass the bar. Days later, Marcos reappointed ten of them.

36. See "Appendix C" for the list of cases and descriptions.

37. We have hired a media expert specializing in the Supreme Court in the Philippines to compile this list of cases. We did not interfere with the selection of cases except for providing the criteria of political significance. The media expert coded these cases without any interference from the authors and selected them based on media salience. The Supreme Court cases that the media considered as newsworthy concern disputes that have a huge public impact and contain elements of heightened conflict involving the interests of the incumbent administration. They can be grouped into the following: cases that (i) involve martial law issuances, rebellion, human rights violations, and national security; (ii) term limits and legitimacy of presidential succession; (iii) elections, appointments, and changes in the political configuration of the legislature; (iv) separation of powers between the executive, legislative, and judicial branches, (v) issues that involve the incumbent's priority programme and other economic issues including fiscal and tax cases; and (vi) corruption. See "Appendix B" and "Appendix C" for further discussion.

38. Due to the expansion of the scope of its judicial review, the Supreme Court has a huge case-load. From 2006 to 2010 , it received an annual average of 16,329 cases and disposed of 9,211. For judicial cases that are decided en banc, the average annual figure is also high, with 730 incoming cases and 327 resolved. See Supreme Court Annual Review, 2006-2010.

39. See mainly Martin \& Quinn, supra note 3; and Hanretty, supra note 3; as well as Dalla Pellegrina et al., supra note 3. Other papers that use non-dynamic simulations include Clinton et al. (2004) and Jackman, supra note 3. 
$i(i=1, \ldots, N)$. Further, we assigned a vote in favour of the incumbent administration of a particular law, ordinance, or government behaviour a value of one $\left(x_{i j}=1\right)$, while the votes against the incumbent received a value of zero $\left(x_{i j}=0\right)$. In order to classify the votes as in favour or against the incumbent administration, we were first concerned about the President being plaintiff or defendant. Then, we considered whether the Court was reviewing presidential and executive orders or was considering the constitutionality of laws passed by Congress, and other issues that concern the interests of the President. In the latter case, we further accounted for whether the President's party had or had not a majority in Congress. ${ }^{40}$

In our study, we have considered the four presidential terms between 1986 and 2010. In particular, breaking the sample according to the administration allows us to check whether the strength of possible support provided to the President by the judges s/he has appointed changes across administrations. Table 2 summarizes the information used to implement the statistical method, in particular, the parameters $J$ and $N$ for each of the four specifications.

The vote of each Justice responds to the personal attributes of the Judge as well as the characteristics of the decision. ${ }^{41}$ In particular, we focused on the Judge's ideal point $\left(\theta_{j}\right)$, which is a latent variable that can be measured indirectly by observing the Judge's manifest opinions on several decisions of the Supreme Court. We also considered a possible case characteristic that adjusts the particular preference of an individual Judge to the relevant dimension when faced with a particular decision $\left(\beta_{i}\right)$. In other words, $\beta_{i}$, which is parallel to the discrimination parameter in IRT models, provides information on how effectively a decision on a given issue can discriminate between Judges on the recovered dimension. We also accounted for a particular location of the decision in the relevant space $\left(\alpha_{i}\right)$. Again, $\alpha_{i}$ is parallel to the difficulty parameter in Two-Parameter IRT models.

Suppose that the excess utility to a given Justice $j$ voting for or against the incumbent President in a particular decision $i$ is the following:

$$
Z_{i j}=\alpha_{i}+\beta_{i} \theta_{j}+e_{i j}
$$

Where the error term $e_{i j}$ is distributed according to a standard normal distribution. Since $z_{i j}$ is a latent variable, we assumed that $x_{i j}=1$ if $z_{i j}>0$ and $x_{i j}=0$ if $z_{i j} \leq 0$.

Moreover, the model is not identified unless additional restrictions are imposed. In the event that additional restrictions are imposed, it is possible to either normalize the ideal points or constrain the position of two of the Justices in the one-dimensional latent space, in such a way that all of the other Justices' ideal points are estimated in relation to the two fixed positions. ${ }^{42}$ We chose to employ the latter empirical strategy and we also assumed standard normal priors for the item parameters.

The estimated judicial ideal points are presented in one relevant dimension. These estimations typically follow the left-right or liberal-conservative dimension. But, in the

40. This should also avoid the critique raised by Hanretty (2013) concerning the fact that locations generated by IRT models applied to databases in which individual votes are coded according to judges' concurring, and dissenting opinions only identify judges' propensity to dissent rather than their political attitudes.

41. The cases are coded based on whether or not it serves the interests of the incumbent administration at the date of the Court's decision.

42. Normalized estimates typically show better convergence properties compared to non-normalized ones (see Bafumi et al., supra note 3). However, here we use the standard procedure followed in the literature, since convergence does not appear to be a relevant problem in our estimates. 
Table 2. Estimating judicial ideal points, 1986-2010

\begin{tabular}{lccll} 
President & $\begin{array}{c}\text { Number of } \\
\text { justices }(\mathbf{J})\end{array}$ & $\begin{array}{c}\text { Number of } \\
\text { cases }(\mathbf{N})\end{array}$ & Prior pro-president (+2) & Prior anti-president (-2) \\
\hline C. Aquino (1986-92) & 21 & 50 & Marcelo Fernan & Abraham Sarmiento \\
Ramos (1992-98) & 25 & 24 & Jose Vitug, Santiago Kapunan, Andres Narvasa & Isagani Cruz, Hilario Davide \\
Estrada (1998-2001) & 19 & 10 & Consuelo Ynares Santiago, Santiago Kapunan & Flerida Ruth Romero, Reynato Puno, Jose Vitug \\
Arroyo (2001-10) & 37 & 38 & Teresita Leonardo De Castro, Renato & Consuelo Ynares Santiago, Santiago Kapunan, \\
& & & Corona & Bernardo Pardo \\
\hline
\end{tabular}


context of the Philippines, the obvious approach may be favourable-unfavourable to the incumbent President, given the political context and the transition period included in our dataset. Since our analysis is presented by presidential terms, it seems intuitive to consider pro-administration and anti-administration as the representative dimension for analysis.

Through a careful analysis of the dissent opinions, we began utilizing this method by setting two Justices to -2 (opinions less favourable to the administration) and +2 (opinions more favourable to the administration) respectively per each fitted model. If the relevant dimension is correctly identified, we expect these Justices to be at the extremes, while the values corresponding to the other Justices should fall between -2 and +2 . If, however, we incorrectly identified the relevant dimension, the estimated model should experience problems of convergence or Justices situated in less likely positions. ${ }^{43}$ In order to address these shortcomings, we have estimated ideal points with multiple combinations of Justices in -2 and +2 , according to our priors. As a result, we therefore produced several estimations of ideal points so as to guarantee robustness, and then averaged each Justice's records obtained within each term. We summarize in Table 2 the information concerning all Justices we have combined in the positions -2 and +2 . In particular, one may notice that only two Justices have been put in the extreme positions during Aquino's term, i.e. Sarmiento and Fernan, respectively set at -2 and +2 . More than two Justices alternate at the extreme positions during other presidential terms. ${ }^{44}$

We used the MCMC pack for R to estimate the model. ${ }^{45}$ The well-known advantage of this approach is that it uses Bayesian Markov Chain Monte Carlo to provide for robust intervals for the estimated parameters. Each model was run for 1,200,000 iterations, discarding the first 2,000 as burn-in. The thinning interval that we used in the simulations is 10 . Gibbs sampling was adopted.

The results of our estimations are presented in Figures 1 to 4 in terms of average estimated ideal points conditional on presidential appointments. Let us start with the results for Aquino (1986-92), presented in Figure 1. As one can observe at the bottom of the table there is no correlation between the estimated ideal points and presidential appointments. That is hardly surprising, since all Justices were effectively appointed by her (with only three being previous choices of Marcos).

The results for Ramos (1992-98), presented in Figure 2, are more interesting. There is a strong correlation between estimated ideal points and presidential choices, namely those Justices appointed by President Ramos are more likely to be clustered in a position favourable to the administration (the correlation is 0.53 ). ${ }^{46}$ Although, to a large extent, Ramos's coalition was perceived as a political majority continuing from Aquino, the results show a significant difference between those Justices appointed after 1992 (mostly favourable to the administration) and those appointed before 1992 (mostly unfavourable to the administration).

The results for Estrada (1998-2001) confirm the pattern, as we can see from Figure 3. There is some degree of correlation between estimated ideal points and presidential choices,

43. In our case standard diagnostic tests suggest that convergence is achieved in all simulations.

44. This leads to (average) ideal points which are different from +2 and -2 even for judges which have been set at the extremes, apart from Sarmiento and Fernan in Aquino's term.

45. See Martin et al. (2005).

46. $t$-test for equal means (see bottom of Table D2 in "Appendix D") suggests that there is significant difference in the behaviour of Judges appointed by Ramos compared to those who have not been appointed by him. 

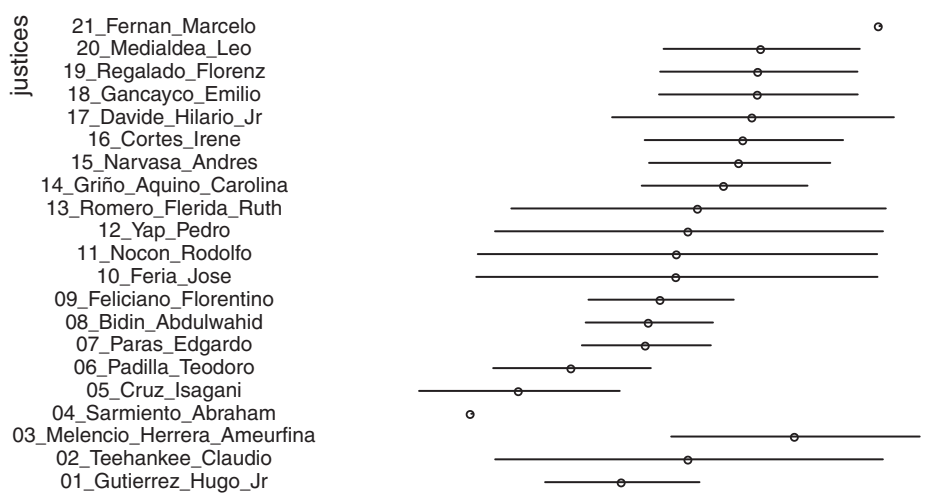

\begin{tabular}{|c|c|c|c|c|c|c|c|}
\hline$\Gamma$ & $\top$ & $T$ & T & $T$ & $T$ & $T$ & T \\
\hline-4 & -3 & -2 & -1 & $\begin{array}{c}0 \\
\text { idpoints }\end{array}$ & 1 & 2 & 3 \\
\hline
\end{tabular}

Figure 1. Average ideal points, Aquino term, 1986-92 (including priors).

NOTES: Justices 1 to 3 have not been appointed by Aquino; Justices 4 to 21 have been appointed by Aquino. Correlation between estimated ideal points and dummy for appointment ( $=1$ if appointed by Aquino): -0.0558 (not significant). Correlation weighted for the standard deviation of idpoints: -0.0225 (not significant). Median justice: Teehankee Claudio [idpoint: 0.13421 ; $95 \%$ confidence interval: $-1.765618 ; 2.034038]$.
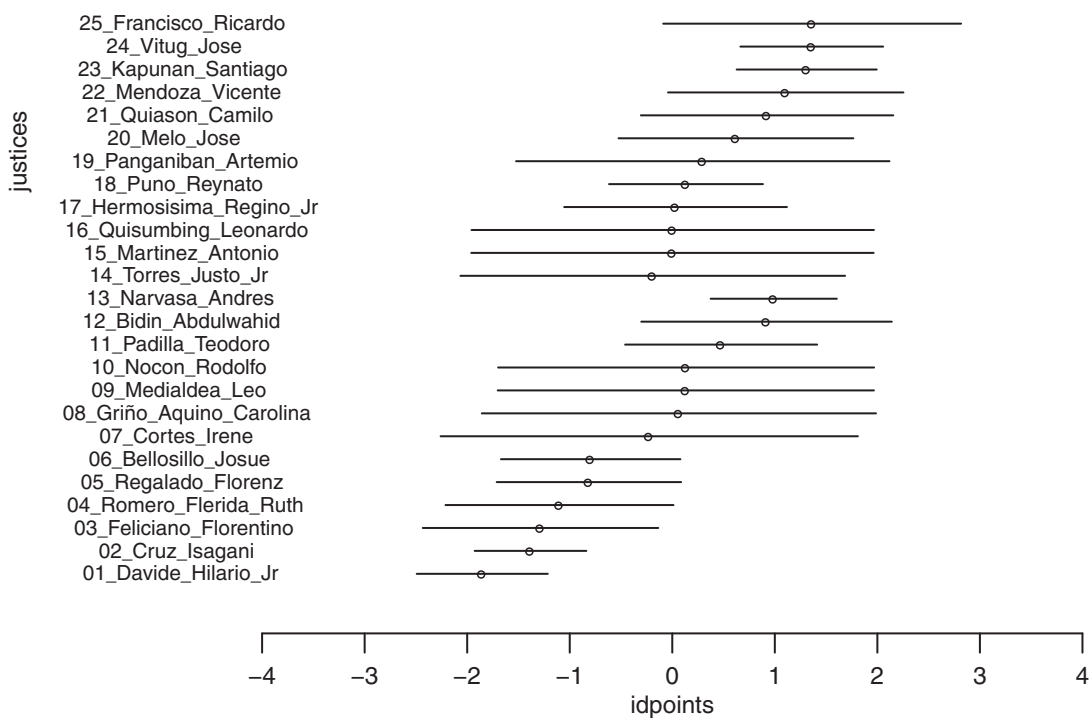

Figure 2. Average ideal points, Ramos term, 1992-98 (including priors).

NOTES: Justices 1 to 13 have not been appointed by Ramos; Justices 14 to 25 have been appointed by Ramos. Correlation between estimated ideal points and dummy for appointment $(=1$ if appointed by Ramos): 0.5348 (significant at $1 \%$ level). Correlation weighted for the standard deviation of idpoints: 0.5861 (significant at $1 \%$ level). Median justice: Medialdea Leo [idpoint: 0.132028 ; $95 \%$ confidence interval: $-1.702531901 .96658810]$. 

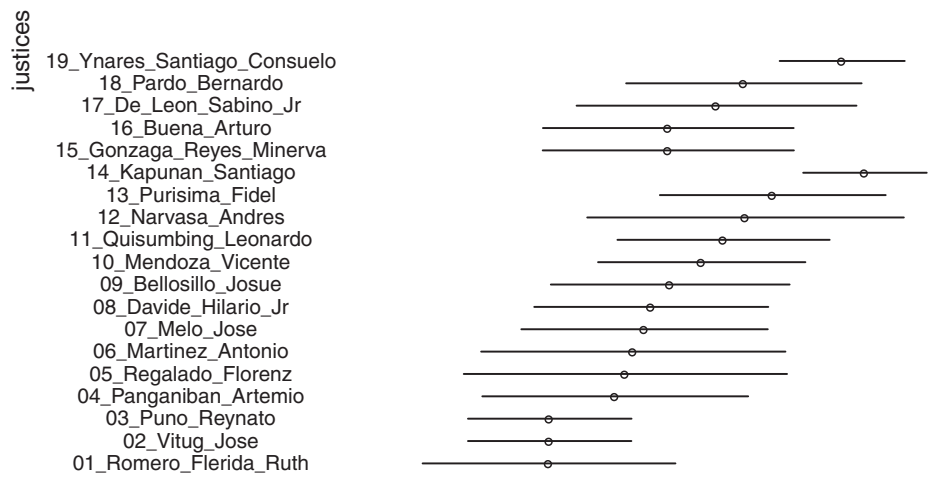

\begin{tabular}{|c|c|c|c|c|c|c|c|}
\hline Г & $T$ & $T$ & $T$ & $T$ & $T$ & $\top$ & $T$ \\
\hline-4 & -3 & -2 & -1 & $\begin{array}{c}0 \\
\text { dpoint }\end{array}$ & 1 & 2 & 3 \\
\hline
\end{tabular}

Figure 3. Average ideal points, Estrada term, 1998-2001 (including priors).

NOTES: Justices 1 to 14 have not been appointed by Estrada; Justices 15 to 19 have been appointed by Estrada. Correlation between estimated ideal points and dummy for appointment $(=1$ if appointed by Estrada): 0.3225 (not significant). Correlation weighted for the standard deviation of idpoints: 0.3390 (not significant). Median justice: Buena Arturo [idpoint: -0.16765 ; 95\% confidence interval: -1.4210030 1.08570633].

where those Justices appointed by President Estrada are more likely to be clustered in a position favourable to the administration (the correlation is 0.32 ). However, given the political context of this term and the few choices to the Court, it is notable that the positive correlation is not statistically significant.

Finally, the results for Arroyo (2001-10) are also in line, as observed in Figure 4. The correlation in her case is 0.47 (strongly significant), confirming that Justices appointed by Arroyo form a pro-administration cluster, where Justices appointed by previous Presidents seem to be less pro-administration. ${ }^{47}$

It is also interesting to note the difference between the estimated ideal points of Justices appointed by Arroyo during her two terms as President. Five out of eight Justices appointed during her first term, from 2001 to 2004, have negative ideal points: Alicia Austria Martinez, Romeo Callejo, Adolfo Azcuna, Conchita Carpio Morales, and Antonio Carpio. Except for a couple of Justices, all Justices appointed during her second term have positive ideal points. This may be a reflection of the shift in the nature of the Arroyo presidency. During her first term, she was sworn in as President by Chief Justice Hilario Davide in the midst of a peaceful people's uprising following an aborted impeachment trial of Estrada on the grounds of corruption, the resignation of key Cabinet officials, and the withdrawal of support by the police and the military. Her first term was a response to the public clamour to end corruption and to strengthen the institutions of democratic governance which were impaired by the rise

47. All the reported average scores include priors -2 and +2 . Average scores excluding priors confirm these results. Excluding priors, correlations are $-0.07,0.55,0.30$, and 0.46 , respectively. In addition, at the bottom of Figures 1 to 4 we report correlations weighted for the reciprocal of each ideal point standard deviation. Results confirm our previous considerations. 


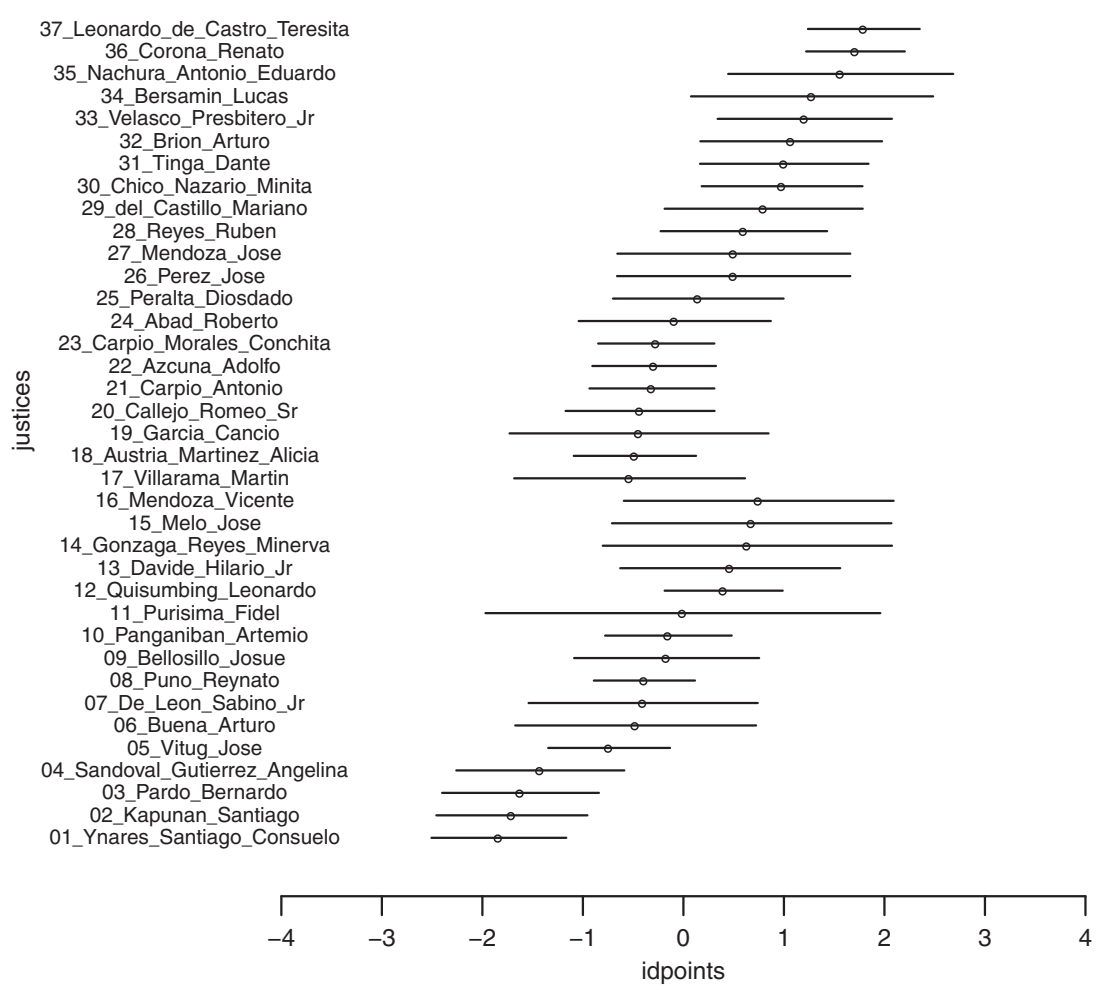

Figure 4. Average ideal points, Arroyo terms, 2001-10 (including priors).

NOTES: Justices 1 to 16 have not been appointed by Arroyo; Justices 17 to 37 have been appointed by Arroyo. Correlation between estimated ideal points and dummy for appointment ( $=1$ if appointed by Arroyo): 0.4691 (significant at $1 \%$ level). Correlation weighted the standard deviation of idpoints: 0.5151 (significant at $1 \%$ level). Median justice: Purisima Fidel [idpoint: -0.00504 ; $95 \%$ confidence interval: $-1.96922381 .9591388]$.

of cronyism under Estrada. Thus, the Justices appointed during this period were likely to share the preferences not only of Arroyo, but also the loose group that put her in power. A number of them were career Justices, former officials of the previous President, or played a role in the impeachment of Estrada.

Her presidency took a different turn during her second term. She lost support from her progressive allies and supporters when she ran as President and won by a slim margin in a contested election. Her popularity dropped as corruption scandals erupted involving members of the first family. There were calls from civil society for her to resign. There was also discontent from the military. A number of cases that were brought to the Supreme Court involved challenging the constitutionality of presidential moves promulgated in response to the crisis she faced as President. The most salient involved the curtailment of civil rights and liberties. ${ }^{48}$ In this context, the incentives for Arroyo to appoint Justices whose preferences were closer to hers became more imperative.

48. See G.R. No. 169838 \& G.R. No. 169777, for instance. 
In Table 3, we summarize the information about outlier Justices, that is, those Justices that are unexpectedly unfavourable to the administration that appointed them (we excluded the Aquino administration for which there is no correlation between ideal points and presidential appointment). ${ }^{49}$ It includes one Justice from Ramos's term, two Justices from Estrada's term, and eight Justices from Arroyo's terms (which is unsurprising given her long term in office). As we can observe, there is some pattern explaining why these Justices are less inclined to behave as predicted. Most of them are career judges who served as Justices on the Court of Appeals before moving up to the Supreme Court. They may share a judicial philosophy acquired and developed from their judicial practice. ${ }^{50}$ Thus, it appears that the ideal points of career judges, especially those who served in the Court of Appeals prior to becoming Supreme Court Justices, are relatively farther from the appointing President. It may be the case that the institutional constraints are harder for the appointing President to ignore when faced with candidates who are career judges and who rose up the ranks of the judiciary.

It is interesting to compare the degree of correlation between the Justices' estimated ideal points and the President who appointed them with respect to the relationship with the legislature during periods of crisis or threats to the presidency. For instance, it is interesting to note that the lowest correlation is observed during the period of Estrada. All Justices appointed by Estrada have judicial experience, half of whom are women. His landslide victory at the polls coupled with his coalition party's win in the Senate, may have provided him with less incentive to control the Court. On the other hand, it may also be due to the fact that the period corresponds to the early periods of his presidency. Its consequences, however, prove to be crucial in the incumbent's ability to govern during periods of political crisis, in which the High Court's intervention was often sought to have the final say in their settlement. This becomes apparent for Estrada when the deliberations over his guilty behaviour continued in the streets after an aborted impeachment proceedings in the Senate, and was finally settled by the Court when Arroyo was sworn into office.

This lesson of substituting judicial control over the lack of legislative and popular support did not escape Arroyo, who won by a slim margin in her second term. Her government's responses to accusations of electoral fraud, corruption, and other criticism from the members of the opposition and civil society groups, along with measures to deal with coup attempts, were likewise questioned before the Supreme Court. At that point in time, the High Court was composed of her second-term appointees, who have closer ideal points with her. This politicization in the judiciary under her second term culminated in the midnight appointment of Corona as Chief Justice.

The ideal point estimation also aids in identifying the median Justice in the Philippine Supreme Court for each administration. The role of the median Judge is important in determining judicial outcomes and an aid in characterizing the position of the Court. ${ }^{51}$

All median Justices for each administration were not original appointees by the incumbent administration. Claudio Teehankee, the median Judge for the Aquino administration, was appointed by Marcos. Leo Medialdea, the median Judge for the Ramos administration, was

49. Outlier Justices can be identified in Figures 1 to 4 (see also Tables D1 to D4 in "Appendix D") by being appointed by the President to whom the term refers (1 in the last column of Tables D1 to D4) while assuming a position which is relatively against the appointer herself/himself (negative average ideal point).

50. See, for instance, Sanchez et al. (2011) and Kapiszewski (2011).

51. See Martin et al. (2004). 
Table 3. Outlier Justices, 1986-2010

\begin{tabular}{|c|c|c|c|c|c|}
\hline Justice & $\begin{array}{l}\text { Appointer } \\
\text { President }\end{array}$ & $\begin{array}{l}\text { Ideal } \\
\text { point }\end{array}$ & Term & $\begin{array}{l}\text { Age at } \\
\text { appointment }\end{array}$ & Background \\
\hline Justo Torres, Jr. & Ramos & -0.19 & 1996-97 & 69 & Career judge, former Justice of the Court of Appeals \\
\hline Minerva Gonzaga Reyes & Estrada & -0.17 & 1999-2002 & 68 & Career judge, former Justice of the Court of Appeals \\
\hline Arturo Buena & Estrada & -0.17 & 1999-2002 & 67 & Career judge, former Justice of the Court of Appeals \\
\hline Martin Villarama, Jr. & Arroyo & -0.56 & 2009-present & 63 & $\begin{array}{l}\text { Career judge, former Justice of the Court of Appeals (included in the } \\
\text { shortlist of candidates nine times) }\end{array}$ \\
\hline Alicia Austria Martinez & Arroyo & -0.48 & $2002-09$ & 62 & $\begin{array}{l}\text { Appointed by Arroyo during first term, career judge, former Justice of the } \\
\text { Court of Appeals }\end{array}$ \\
\hline Cancio Garcia & Arroyo & -0.44 & $2004-07$ & 67 & Career judge, former Justice of the Court of Appeals \\
\hline Romeo Callejo & Arroyo & -0.43 & 2002-07 & 65 & $\begin{array}{l}\text { Appointed by Arroyo during first term, career judge, former Justice of the } \\
\text { Court of Appeals }\end{array}$ \\
\hline Antonio Carpio & Arroyo & -0.31 & 2001-present & 52 & $\begin{array}{l}\text { Appointed by Arroyo during first term, bypassed by Arroyo for Chief } \\
\text { Justice, Acting Chief Justice, highest vote from the JBC for the position } \\
\text { of Chief Justice (2012) }\end{array}$ \\
\hline Adolfo Azcuna & Arroyo & -0.29 & 2002-09 & 63 & $\begin{array}{l}\text { Appointed by Arroyo during first term, member of the } 1986 \text { Constitutional } \\
\text { Commission, member of the } 1971 \text { Constitutional Convention }\end{array}$ \\
\hline Conchita Carpio Morales & Arroyo & -0.27 & $2002-11$ & 61 & $\begin{array}{l}\text { Appointed by Arroyo during first term, career judge, former Justice of the } \\
\text { Court of Appeals, appointed as Ombudsman by B. Aquino after } \\
\text { retirement as Associate Justice }\end{array}$ \\
\hline Roberto Abad & Arroyo & -0.09 & 2009-present & 65 & One of the candidates interviewed by the JBC for Chief Justice \\
\hline
\end{tabular}


an Aquino appointee. Arturo Buena and Fidel Purisima, the median Judges for the Estrada and Arroyo administrations respectively, were Ramos appointees.

The median Justices also tend to predict the outcome of the cases in our set of observations most of the time, confirming their position as the swing voters. For instance, Teehankee, Medialdea, and Buena's vote coincided with the final outcome of the cases in our study except for one case. It should also be underscored that a number of the cases were decided unanimously, but in those cases where the Court was divided, the votes of the median Judge coincided with the majority most of the time.

For all administrations, most Justices appointed by the incumbent administration also tend to lie to the right of the median Judge, implying that their policy preferences are more pro-incumbent. In the case of Arroyo appointees, we can again observe the difference between the Justices appointed during her first and her second terms. Most Justices appointed by Arroyo during her first term of office lie to the left of the median Judge, except for Renato Corona, who was appointed Chief Justice, Dante Tinga, and Minita Chico Nazario. Except for a couple of Justices, those who were appointed during her second term all lie to the right of the median.

The position of the median Justice between the Aquino and Ramos period did not move. This reflects relative stability in the Court's share of Justices supporting the administration. On the other hand, the median Justice position shifted and became negative during the Estrada administration, reflecting a move towards a less favourable position with regard to the President. The median Justice moved more towards the President (although preserving a negative ideal point) during the Arroyo administration.

The estimation of the ideal points also provides us with a way to characterize the location of the Chief Justices for each administration. For instance, Claudio Teehankee, the first Chief Justice of the post-Marcos Supreme Court, is the median Judge during the Aquino administration. Pedro Yap, another Aquino Chief Justice appointee, lies next to Teehankee. Ramos did not appoint any Chief Justice during his term, as Andres Narvasa, an Aquino appointee, served as Chief Justice until after the end of Ramos's term. Ramos, however, appointed two Justices who later served as Chief Justices during the period of Arroyo: Artemio Panganiban and Reynato Puno. As Chief Justices under Arroyo, both lie to the left of the median. Hilario Davide was appointed Chief Justice under the Estrada government, and his ideal point for this period lies to the left of the median. Thus, it appears that the informal rule of appointing the most senior Associate Justice as Chief Justice has served as a constraint on the part of the President to appoint someone who is closest to his or her ideal point. Given the informal rule of seniority, the most senior candidate for the position of Chief Justice is most likely to be an appointee of previous administrations.

While it is beyond the scope of this study to provide a detailed analysis of the estimated ideal points of Justices with their post Supreme Court careers, a comparison within the Arroyo administration is consistent with our theory. Some of the Justices with estimated negative ideal points became law professors and columnists in leading newspapers. Former Associate Justices Angelina Sandoval Gutierrez and Josue Bellosillo are the current Deans of the College of Law at the Pamantasan ng Lungsod ng Maynila and Centro Escolar University, respectively. Former Associate Justices Adololfo Azcuna and Jose Vitug are members of the Academic Council of the Philippine Judicial Academy, the former also being the Chancellor. Former Chief Justice Artemio Panganiban writes a column for a leading and 
newspaper, and Associate Justice Isagani Cruz was also a columnist. Former Associate Justices Alicia Austria Martinez and Romeo Callejo are part of the newly created SC Committee that is tasked with probing corruption in the judiciary. Former Associate Justice Conchita Carpio Morales, who has an estimated negative ideal point during Arroyo, was later appointed Ombudsman by B. Aquino III. On the other hand, Former Associate Justice Minita Chico Nazario, who has an estimated positive ideal point, was appointed by Arroyo as Chairperson of the state-owned Philippine National Oil Company-Exploration Corporation, also during the period when there was an electoral ban on appointments. Former Associate Justice Dante Tinga, who also has a positive ideal point, ran for public office.

Thus, the estimation of the ideal points through the MCMC method provides us with a more objective characterization and analysis of the Supreme Court as well as of the individual Justices. The positive analysis allows us to provide answers to normative questions such as: what institutional features are effective in the case of the Philippines and other restored democracies that share the same features? Such methods are needed, considering the series of events that put the Supreme Court in the spotlight, and to avoid a biased or partisan analysis.

\section{CONCLUSION}

This paper presents an application of ideal point estimation to the Supreme Court of the Philippines. We did find a strong indication of a relationship between judicial ideal points and presidential appointments. Our results indicate some possible political allegiance by Filipino Justices and the President (very significant in the Ramos and Arroyo terms). Our estimated model is consistent with interpretations offered in previous work. ${ }^{52}$

Our results show that our estimation of the ideal points of the Justices in the Philippines along a government-opposition dimension does a relatively good job at characterizing Justice's preferences. Due to the specific institutional characteristics of the Philippines, the usual dimension based on ideology poses a problematic exercise. The salient and relevant dimension is government-opposition. We find a strong correlation between the estimated ideal points of the Justices and the incumbency of the President who appointed them.

There are two suggested reasons behind this. One lends support to the theory that the President minimizes the distance between his ideal point and the Justices. Depending on the presence or absence of institutional constraints on the part of the President in appointing Justices closest to his ideal point, then the shorter or the longer is this distance. The other lies in the incentives of judges to engage in strategic behaviour. In a context, where the President exercises monopoly power over the political resources and in a situation where judges have career aspirations outside the Court, their votes reflect both their strategic behaviour and their respective policy preferences.

The study also provides a more specific way to describe the Court and the Justices. For instance, it aids in identifying and characterizing the median Judge. Quite notably, we find that $\mathrm{s}$ he is never an appointee of the incumbent President. The positive analysis has implications for judicial reforms, especially with respect to the selection and appointment process and the appropriate institutional design that would guarantee the Court's independence. ${ }^{53}$

52. See Escresa \& Garoupa, supra note 2 .

53. For instance, the impeachment of the Chief Justice sparked a debate whether the Judicial and Bar Council actually served to dampen political patronage in the appointment process or whether the older procedure that required approval by the Congressional Commission on Appointments was more successful in curbing it; see Joaquin Bernas, 
Our study also contributes to a greater understanding of the configuration of the Court in relation to the President and the executive in democracies that were previously under authoritarian rule. The function of the Supreme Court under the Marcos dictatorship was explored by Tate and Haynie (1993, 1994). The extent of institutional and constitutional innovations and democratic features have been able to ensure the independence of the Court in performing its proper role in society is much less obvious.

Although the Supreme Court structure is the same in the Philippines as in the US, due to a significant transplant effect, the political and social context varies. Yet our results concerning judicial ideal points are actually not very different from previous studies about the Supreme Court of the US. To a large extent, such a conclusion is surprising given the standard accounts of judicial behaviour in weak democracies. Clearly, the underlying reasons differ significantly as we have explained, but it is important to recognize that the perceived differences between the Supreme Courts of the US and of the Philippines are less striking.

\section{REFERENCES}

Abinales, Patricio N., \& Donna J. Amoroso (2005) State and Society in the Philippines, Lanham, MD: Rowman \& Littlefield.

Bafumi, Joseph, Andrew Gelman, David K. Park, \& Noah Kaplan (2005) "Practical Issues in Implementing and Understanding Bayesian Ideal Point Estimation." 13 Political Analysis 171-87.

Clinton, Joshua, Simon Jackman, \& Douglas Rivers (2004) "The Statistical Analysis of Roll Call Data." 98 American Political Science Review 355-70.

Dahl, Robert A. (1957) "Decision-making in a Democracy: The Supreme Court as a National Policymaker." 6 Journal of Public Law 279-95.

Dalla Pellegrina, Lucia, Nuno Garoupa, \& Shirley Lin (2012) "Judicial Ideal Points in New Democracies: The Case of Taiwan." 7 National Taiwan University Law Review 123-65.

Dewan, Torun, \& Arthur Spirling (2011) "Strategic Opposition and Government Cohesion in Westminster Democracies." 105 American Political Science Review 337-58.

Earl, Jennifer, Andrew Martin, John McCarthy, \& Sarah Soule (2004) "The Use of Newspaper Data in Collective Action." 30 Annual Review of Sociology 65-80.

Eisenstadt, Todd (2006) "Mexico's Postelectoral Concertacesiones: The Rise and Demise of a Substitutive Informal Institution," in Gretchen Helmke \& Steven Levitsky, eds., Informal Institutions and Democracy: Lessons from Latin America, Baltimore: Johns Hopkins, 227-48.

Escresa, Laarni, \& Nuno Garoupa (2012) "Judicial Politics in Unstable Democracies: The Case of the Philippine Supreme Court, An Empirical Analysis 1986-2010." 3 Asian Journal of Law and Economics $1-37$.

Escresa, Laarni, \& Nuno Garoupa (2013) "Testing the Logic of Strategic Defection: The Case of the Philippine Supreme Court, An Empirical Analysis 1986-2010.” 21 Asian Journal of Political Science 189-212.

Flores, Mikhail Franz (2013) "Body Formed to Probe Judicial Corruption.” Businessworld, 17 October, online: $<$ http://www.bworldonline.com/content.php?section=Nation\&title=Body-formed-to-probejudicial-corruption\&id $=78110>$.

Franzosi, Roberto (1987) "The Press as a Source of Socio-Historical Data: Issues in the Methodology of Data Collection from Newspapers." 20 Historical Methods: A Journal of Quantitative and Interdisciplinary History 5-16.

(F'note continued)

"Why a Judicial and Bar Council?" Philippine Daily Inquirer, 25 June 2012 (online: <http://opinion.inquirer.net/ 31391/why-a-judicial-and-bar-council >). 
Garoupa, Nuno, Veronica Grembi, \& Shirley Lin (2011) "Explaining Constitutional Review in New Democracies: The Case of Taiwan." 20 Pacific Rim Law and Policy Journal 1-40.

Gatmaytan, Dante B., \& Cielo Magno (2011) "Averting Diversity: A Review of Nominations and Appointments to the Philippine Supreme Court, 1988-2008." 2 Asian Journal of Comparative Law $1-18$.

Ginsburg, Tom (2003) Judicial Review in New Democracies: Constitutional Courts in Asian Cases, New York: Cambridge University Press.

Gloria, Glenda (2003) We Were Soldiers: Military Men in Politics and the Bureaucracy, Quezon City: Friedrich Ebert Stiftung.

Hanretty, Chris (2012) "Dissent in Iberia: The Ideal Points of Justices of the Spanish and Portuguese Constitutional Tribunals." 51 European Journal of Political Research 671-92.

Hanretty, Chris (2013) "The Decisions and Ideal Points of British Law Lords." 43 British Journal of Political Science 703-16.

Helmke, Gretchen (2002) "The Logic of Strategic Defection: Court-Executive Relations in Argentina under Dictatorship and Democracy." 96 American Political Science Review 291-303.

Helmke, Gretchen, \& Steven Levitsky (2004) "Informal Institutions and Comparative Politics: A Research Agenda." 2 Perspectives on Politics 725-40.

Hix, Simon, Abdul Noury, \& Gérard Roland (2006) "Dimensions of Politics in the European Parliament." American Journal of Political Science 494-520.

Jackman, Simon (2001) "Multidimensional Analysis of Roll Call Data via Bayesian Simulation: Identification, Estimation, Inference, and Model Checking." 9 Political Analysis 227-41.

Kapiszewski, Diana (2011) "Tactical Balancing: High Court Decision Making on Politically Crucial Cases." 45 Law and Society Review 471-506.

Kasuya, Yuko (2005) "Patronage of the Past and the Future: Legislators' Decision to Impeach President Estrada of the Philippines." 18 The Pacific Review 521-40.

Lande, Carl (2001) "The Return of 'People Power' in the Philippines." 12 Journal of Democracy 88-102.

Martin, Andrew D., \& Kevin M. Quinn (2002) "Dynamic Ideal Point Estimation via Markov Chain Monte Carlo for the U.S. Supreme Court, 1953-1999." 10 Political Analysis 134-53.

Martin, Andrew, Kevin Quinn, \& Lee Epstein (2004) "The Median Justice on the United States Supreme Court." 83 North Carolina Law Review 1275-322.

Martin, Andrew, Kevin M. Quinn, \& Jong Hee Park (2005) "MCMC Pack: Markov Chain Monte Carlo (MCMC) Package (2005)," online: <http://mcmcpack.wustl.edu/> (last accessed 26 April 2011).

Moraski, Bryon, \& Charles Shipan (1999) "The Politics of Supreme Court Nominations: A Theory of Institutional Constraints and Choices." 43 American Journal of Political Science 1069-95.

Oliver, Pamela, \& Daniel Myers (1999) "How Events Enter the Public Sphere: Conflict, Location, and Sponsorship in Local Newspaper Coverage of Public Events." 105 American Journal of Sociology 38-87.

Peress, Michael (2009) "Small Chamber Ideal Point Estimation." 17 Political Analysis 276-90.

Popova, Maria (2012) Politicized Democracies in Emerging Democracies: A Case Study of Courts in Russia and Ukraine, New York: Cambridge University Press.

Ramseyer, J. Mark, \& Eric B. Rasmusen (2003) Measuring Judicial Independence: The Political Economy of Judging in Japan, Chicago: University of Chicago Press.

Ramseyer, J. Mark, \& Eric B. Rasmusen (2006) "The Case for Managed Judges: Learning from Japan after the Political Upheaval of 1993.” 154 University of Pennsylvania Law Review 1879-930.

Rose-Ackerman, Susan, Diane A. Desierto, \& Natalia Volosin (2011) "Hyper-Presidentialism: Powers without Checks and Balances in Argentina and the Philippines." 29 Berkeley Journal of International Law 1-88.

Sanchez, Arianna, Beatriz Magaloni, \& Eric Magar (2011) "Legalist vs. Interpretativist: The Supreme Court and the Democratic Transition in Mexico," in Gretchen Helmke \& Julio Rios-Figueroa, eds., Courts in Latin America. Cambridge: Cambridge University Press.

Shipan, Charles, \& Megan Shannon (2003) "Delaying Justice(s): A Duration Analysis of Supreme Court Nominations." 47 American Journal of Political Science 654-68. 
Smith, Charles, \& Mark Jorgensen Farrales (2010) "Court Reform in Transitional States: Chile and the Philippines." 13 Journal of International Relations and Development 163-93.

Spirling, Arthur, \& Iain Mclean (2007) "UK OC OK? Interpreting Optimal Classification Scores for the U.K. House of Commons." 15 Political Analysis 85-96.

Tate, C. Neal (1993) "Courts and Crisis Regimes: A Theory Sketch with Asian Case Studies." 46 Political Research Quarterly 311-38.

Tate, C. Neal, \& Stacia L. Haynie (1993) "Authoritarianism and the Functions of Courts: A Time Series Analysis of the Philippine Supreme Court, 1961 -1987." 27 Law and Society Review 707-40.

Tate, C. Neal, \& Stacia L. Haynie (1994) "The Philippine Supreme Court under Authoritarian and Democratic Rule: The Perceptions of the Justices." 22 Asian Profile 209-26.

Vitug, Marites Dañguilan (2010) Shadow of Doubt: Probing the Supreme Court, Quezon City: Public Trust Media Group.

Wetstein, Matthew, C.L. Ostberg, Donald Songer, \& Susan Johnson (2009) "Ideological Consistency and Attitudinal Conflict: A Comparison of the U.S. and Canadian Supreme Courts." 42 Comparative Political Studies 763-92.

Weyland, Kurt (2002) "Limitations of Rational Choice Institutionalism for the Study of Latin American Politics." 37 Studies in Comparative International Development 57-85.

Zucco, Cesar Jr. (2009) "Ideology or What? Legislative Behavior in Multiparty Settings." 71 The Journal of Politics 1076-92.

Zucco, Cesar Jr., \& Benjamin Lauderdale (2011) "Distinguishing Between Influences On Brazilian Legislative Behavior.” 36 Legislative Studies Quarterly 363-96.

\section{APPENDIX A}

Some of the landmark cases that are illustrative of the relationship between the President and the Court are:

Javellana (1973): a six-four majority of the Supreme Court packed by appointees of President Marcos declared the 1973 Constitution not properly ratified, although recognized that the new charter was already applicable. Because of a requirement of two-thirds voting to declare a law unconstitutional, the Court decision effectively allowed the 1973 Constitution to be applied. Although the Justices rebuked the President for the process used to adopt a new Constitution, the decision legitimized the new political regime (with four Justices showing approval for all decisions of President Marcos under martial law). This case considerably undermined the prestige of the Supreme Court in the eyes of the public.

Philippine Long Distance Telephone (PLDT) (1992): the Court reversed a governmental decision to allow more competition on the provision of international telecommunications services. Later it was revealed that the Justice who drafted the opinion of the Court had used PLDT counselling in the writing. Justice Gutierrez took early retirement and the Chief Justice opened an investigation on corruption within the Court. Other similar cases followed later.

People's Initiative for Reforms, Modernization and Action (PIRMA, 1997): the Court started by deciding that the PIRMA endorsed by President Ramos (that is, a constitutional amendment through a people's initiative) was void, and more legislation was required. Essentially, if it were approved, it would have allowed the re-election of President Ramos (there was little time before the new election). 
Lambino (2006): an eight-seven majority dismissed a petition for a constitutional referendum ratifying a proposal of President Arroyo. Because the two-thirds voting requirement was no longer applicable, the decision of the Court effectively undermined the constitutional project of the incumbent President. This decision included 11 separate opinions (six concurring opinions and five dissents). Most of Arroyo's appointees dissented and considered the petition appropriate. The reaction to Lambino included a recusal of Justices who dismissed the petition (including the Chief Justice and the Justice who drafted the majority opinion), the filling of a vacancy on the Court by the Solicitor General, and the legislative preparation of impeachment of Justices who voted against the petition. The retirement of the Chief Justice at the end of 2006 allowed President Arroyo to command a solid majority in the Court. However, by a unanimous vote, the Court rejected a motion to reconsider the petition.

De Castro (2010): a nine-one majority allowed President Arroyo to make so-called midnight appointments to the Supreme Court, in particular replacing the Chief Justice a few days after the presidential election and a month before her own term expired. The majority defended that constitutional provisions against midnight appointments do not apply to the Supreme Court (with five Justices extending the exception to the entire judiciary). Only one Justice entered a dissent concerning lifting the two-month ban (the remaining dissenting Justices opposed the decision on procedural matters).

Biraogo (2010): the importance of the Supreme Court has been reflected in early decisions by the new President Benigno Aquino III. By the time Arroyo's term in office ended in 2010, 14 of the 15 Supreme Court Justices were her appointees and tainted by the De Castro decision. President Benigno Aquino's first two executive promulgations were challenged directly in the Court. Executive Order No. 1 on the establishment of a Truth Commission was declared unconstitutional by the Supreme Court with a vote of ten to five. The Truth Commission was tasked with investigating the cases of corruption under Arroyo. The Supreme Court ruled that it "violates the equal protection clause of the Constitution." Executive Order No. 2 asked for the withdrawal, recall, and revocation of midnight appointments by Arroyo (presidential appointments made within the 60-day constitutional ban prior to election day). Although the Supreme Court granted a "Status Quo Ante Order" only for the case of Bai Omera Dianalan-Lucman, it cast a shadow on the legitimacy of Benigno Aquino's act of appointing and the replacement of the Arroyo appointees with his own.

\section{APPENDIX B}

The Supreme Court has a huge case-load, owing to the expansion of the scope of its powers by the 1987 Constitution. From 2006 to 2010, it received an annual average of 16,329 cases and disposed of 9,211 cases. For judicial cases that are decided en banc, the average annual figure is also high, with 730 incoming cases and 327 resolved for the same period. While almost all important cases that involve constitutionality and disputes that involve separation of powers are decided en banc, there are other cases that reach the court that have no distinguishable interest for the incumbent administration. Thus, putting together a database of cases with which to study judicial behaviour was a challenging task, an issue that is not unique to the Philippines, however, as illustrated by the plurality of selection criteria that 
exists in the literature. What is often adopted reflects the differences in judicial institutional setting, especially with respect to new or emerging democracies. ${ }^{54}$

Choosing cases based on thematic considerations also posed problems in the Philippine context, given the weaknesses associated with characterizing political interests along a clear conservative-liberal policy divide. ${ }^{55}$ Apart from the legal merits of the case, and ideological considerations, what proves to be another decisive factor in explaining judicial outcomes is the existence of informal institutions that allow for the sanctioning of agents outside the formal institutional channels of the court that may include personal network, clientelism or patronage politics. ${ }^{56}$ Thus, a purely legalistic approach in the selection would also tend to omit cases where such mechanisms would be manifest and requires that the selection criteria should be sensitive to both formal and informal institutional mechanisms at play. ${ }^{57}$

The behaviour of justices with respect to the interests of the incumbent would be most apparent in cases where the political stakes for the sitting incumbent are higher. A database was assembled consisting of 125 cases that were decided en banc from 1986 to 2010 and that are representative of politically significant cases. ${ }^{58}$ One hundred and twenty-two of these cases were decided within the four administrations we are concerned with. They cover a variety of issues related to the President. The important common denominators are that they are key to his or her political survival or to the stability of the incumbent administration. Thus, the cases show heightened conflict between the executive and the legislative branches, between the executive and the judiciary, and between the government and the general public interest. The dataset comprise 1,592 individual observations that were coded as either pro- or anti-incumbent. ${ }^{59}$

The cases were selected based on media salience, ${ }^{60}$ Supreme Court documents and publications, including original cases, Supreme Court Reports Annotated (SCRA), and interviews with law professors, including a dean of a college of law, a former justice of the Court of Appeals (who now sits on the Supreme Court). The media sources include newspaper

54. In the case of Argentina, Helmke (2002) selected cases where the state is a party and/or cases that named a decree passed by the incumbent. In the case of the US, Dahl (1957) focused on cases involving constitutionality. In the case of Brazil, Kapiszewski (supra note 50) selected economic cases. Popova (2012) considered the subset of electoral dispute cases in Russia and Ukraine.

55. See, for instance, and Escresa \& Garoupa (2012, 2013), supra note 2.

56. See, for instance, Eisenstadt (2006), Helmke \& Levitsky (2004), and Weyland (2002). For a more recent case in the Philippines, an investigation is being pursued.

57. The Supreme Court has recently created a committee, headed by Associate Justice Marvic Leonen, and which includes two former Associate Justices, to investigate allegations of corruption in the judiciary after the media reports of a certain broker who can allegedly influence the outcome of court decisions; see Flores (2013).

58. An independent media expert was hired to collect and code the data. She covered the Supreme Court and Department of Justice beats as a journalist and served as a researcher for two award-winning books written on the Philippine Supreme Court.

59. The Justices' votes were coded with respect to the interest of the incumbent administration. In cases where the policy in review may have been enforced or implemented by a previous administration, the votes are assessed based on a comparison with the incumbent's policies or whether they belong to the same political coalition. For instance, the continuity or lack of it is obvious in cases tried under C. Aquino that involve a review of the policies that were enacted or implemented under Marcos's martial rule.

60. Supreme Court decisions that the media reports on and considers as newsworthy contain the element of political conflict and provide a way to limit the scope of cases in a manner that takes into account the situational and temporal complexity that surround each case (see, for instance, Oliver \& Myers, 1999). The use of newspaper as a source of data in the social sciences has its own set of caveats. In particular, the selection bias is more pronounced as big events are overreported (see, for instance, Franzosi, 1987). This bias, however, tends to be stable over time (Earl et al., 2004). However, this bias would not pose a problem since these are precisely the cases that we want to capture. 
articles, columns, and articles of different Justices, blogs of different lawyers, and archives of broadcast networks and other multimedia news agencies.

\section{Supreme Court, en banc case selection and locus standing}

The Supreme Court hears both original and appealed cases and engages in both abstract and concrete review. The cases that should be decided en banc are specified in the Constitution and the Internal Rules of Court of the Supreme Court.

According to Article 8 Section 4(2) of the 1987 Constitution, all cases involving the constitutionality of a treaty, international or executive agreement, or law, including the application or operation of presidential decrees, proclamations, orders, instructions, ordinances, and other regulations, shall be decided en banc. Apart from issues of constitutionality, the Constitution also requires an en banc resolution to cases concerning electoral disputes involving the position of the President and the Vice-President (Article 7 Section 4), the disciplining of judges in the lower courts (Article 8 Section 11), the breaking of an impasse when the decision at the division did not reach the required majority (Article 8 Section 4(3), and other cases specified in the Rules of Court.

Other cases in which the Supreme Court should decide en banc as specified in The Internal Rules of the Supreme Court ${ }^{61}$ are:

(a) appealed criminal cases in which the decision imposes the death penalty or reclusion perpetua;

(b) cases raising novel questions of law;

(c) cases affecting ambassadors, other public ministers, and consuls;

(d) cases involving decisions, resolutions, and orders of the Civil Service Commission, the Commission on Elections, and the Commission on Audit;

(e) cases where the penalty recommended or imposed is the dismissal of a judge, the disbarment of a lawyer, the suspension of any of them for a period of more than one year, or a fine exceeding forty thousand pesos;

(f) cases involving the reinstatement in the judiciary of a dismissed judge, the reinstatement of a lawyer in the roll of attorneys, or the lifting of a judge's suspension or a lawyer's suspension from the practice of law;

(g) cases involving the discipline of a Member of the Court, or a Presiding Justice, or any Associate Justice of the collegial appellate court;

(h) cases where a doctrine or principle laid down by the Court en banc or by a Division may be modified or reversed;

(i) cases involving conflicting decisions of two or more divisions;

(j) Division cases where the subject matter has a huge financial impact on businesses or affects the welfare of a community;

61. A.M. No. 10-4-20-SC The Internal Rules of the Supreme Court, 4 May 2010, online: <http://www.lawphil.net/ courts/supreme/am/am_10-4-20-sc_2010.html> (last accessed 8 December 2013). 
(k) other Division cases that, in the opinion of at least three Members of the Division who are voting and present, are appropriate for transfer to the Court en banc;

(l) cases that the Court en banc deems of sufficient importance to merit its attention; and

(m) all matters involving policy decisions in the administrative supervision of all courts and their personnel.

The rules of court also provide for a majority decision and identify that a quorum is reached with eight members. In this case, the majority required to reach a decision is five.

\section{Locus standing}

A citizen can initiate a constitutional inquiry in the High Court if they can prove that they have suffered a direct injury arising from the statute being questioned. However, the Court has been known to relax this particular requirement and entertain petitions if the case is deemed to be of "transcendental importance" and must be settled early. ${ }^{62}$

Based on Supreme Court rulings, taxpayers, voters, and legislators may also be accorded standing if the cases involve constitutional issues and, in the case of taxpayers, there is a claim that the tax measure is unconstitutional or there are irregularities in the disbursement of public funds. In the case of voters, it must be shown that they have a clear interest in the election law that is being challenged, and for legislators to show that it encroaches on their legislative powers. A number of cases in our dataset reflect these kinds of case. ${ }^{63}$

\section{Classification of cases}

The cases involve both abstract and concrete review. The cases are filed by parties who are directly affected by the statute, or concerned citizens whose standing derives from the fact that the issue being deliberated is of transcendental importance or affects them as taxpayers and voters.

The issues can be classified into six groups: ${ }^{64}$

(1) Cases that concern the scope and limits of the president as commander in chief and other executive powers that may infringe on human rights and other rights of the people comprise $21 \%$. While the post-dictatorship administration initiated moves to curtail the powers of the military, the president also relied on it in response to coup d'état and civilian opposition.

a. Martial law cases: These cases refer to promulgations, laws, or institutions enacted, implemented, or established under martial law, as well as the review or reopening of famous cases during the Marcos dictatorship.

b. Rebellion cases: The government's responses to military adventurism and alleged attempts from the left to topple the government were questioned before the Court.

\footnotetext{
62. See G.R. No. 138570 Bayan v. Zamora and G.R. No. 151445 Lim v. Executive Secretary.

63. See G.R. No. 171396 David v. Arroyo.

64. Some of the cases touch on the people's broad social and economic rights but were also classified based on the immediate political interests of the incumbent. For instance, cases involving the newly created autonomous regions in Muslim Mindanao and in the Cordillera are a recognition of the social and cultural rights of the religious and ethnic minorities, but also have an impact on the political configuration in the country.
} 
In particular, whether the measures were constitutional or whether there was an exercise of abuse of discretion on the part of the President.

c. Security cases: These involve issues concerning national security. After the Senate rejected a treaty that would allow for the continued stay of US military bases in the Philippines in 1991, the justification for the continued presence and deployment of US troops in the country has remained a contentious issue.

d. Human rights cases: The incumbent's measures in dealing with members of the opposition, people's organizations, and other members of civil society have also been questioned before the Court for encroaching on human rights.

e. Freedom of information, rights to privacy, and other cases: Other rights such as the freedom to access information about matters crucial to the public interest is protected by the Constitution, and the Court has been the venue for the extent of interpretation of such rights.

(2) Cases that involve moves to extend executive term limits through constitutional amendments and cases questioning the legitimacy of presidential succession arising from the two people's uprising comprise $4 \%$.

a. The turnover of power to new leaders following the country's two cases of People Power in 1986 and 2001 has been the subject of landmark legal disputes. The Court has ruled that Corazon Aquino's government was the de facto and de jure government while Arroyo's ascension as President in 2001 was constitutional.

b. Except for C. Aquino, all Presidents who had served under the 1987 Constitution have tried to amend or revise the Charter, mostly in their alleged aim to change the term limits of the President and other public officials to extend their stay in power.

(3) Cases involving elections, presidential appointments, and other events that led to changes in the political configuration of the legislature consist of $24 \%$.

a. Election cases: This set of cases relates to questions concerning electoral outcomes and procedures involved in the holding of elections. The Court has settled electoral disputes involving the President in 1992 and the Vice-President in 2004. The Court has also suspended or paved the way for the holding of elections and reviewed contracts concerning poll automation.

b. Appointment cases: The president's appointments have been challenged through the Commission on Appointments, especially when his or her appointee did not fit the requirements stated in the Constitution.

c. Political configuration cases: These cases refer to changes in the composition of the Senate, Congress, and local governments that would affect the power of the President to effectively govern, especially in a context where individual membership to a political party and coalitions are very fluid and shifting.

d. Laws that pave the way for the creation of new political areas have an effect on the presidency. This includes the creation of the Autonomous Region of Muslim Mindanao and the Cordillera Administrative Region that is part of the 
government's peace programme. The creation of some districts, however, as seen under the Arroyo administration, is seen to accommodate her interests and her allies.

(4) Each incumbent has their respective priority projects and economic programmes, as well as priority in budgetary allocation and measures to generate revenue. Disputes questioning their legality or procedural irregularity comprise $28 \%$ of cases.

a. Priority projects: Some of the projects pursued by each administration were questioned for their constitutionality or illegality. The Court has stopped some of them.

b. Tax cases: These cases involve questions of the constitutionality of some of the new tax measures as well as cases of tax evasions or tax favours granted to firms owned by or affiliated with the opposition.

c. Budget cases: The Court has settled questions concerning the parameters of the legislative's and executive's powers, and the national and the local government's power over the appropriation and disbursement of the budget. This also includes the President's exercise of his or her veto powers as well the automatic appropriation for debt service in the national budget.

d. Land cases: Agrarian reform is a centrepiece programme that started in the Aquino administration to address rural poverty and unrest. However, the political and economic power of the country's elite is tied to land ownership. Disputes have reached the High Tribunal.

(5) Cases of corruption involving the President, their family, and their political supporters and allies comprise $15 \%$.

a. While some of the government's priority projects were questioned in the High Court because of irregularities allegedly arising from a corrupt transaction, these cases of corruption allegations involve the President, their families, and allies.

b. This also includes cases questioning the scope of powers of a quasi-judicial body to recover ill-gotten wealth and properties, especially those from the Marcoses and their cronies. Created under the Aquino administration, the cases involving the PCGG have remained important since some of the Marcos allies and members of the Marcos family came back to support candidates and even run for political positions.

(6) The remaining $8 \%$ of cases involve other issues of the separation of powers between the executive, legislative, and judicial branches. 


\section{APPENDIX C}

\section{Case number and classification}

Locus standing:

concerned citizens,

taxpayers, voters Case description

YEAR

I. Scope and limits of the President as Commander in

Chief and other executive powers that may infringe

on human rights and other rights of the people

G.R. No. 72670 Galman v. Sandiganbayan

Retrial of Criminal Cases Nos. 10010 and 10011: assassination of former 1986

G.R. No. L-54558 Olaguer v. Military

Commission

G.R. No. L-69866 Aberca et al. v. Ver et al.

G.R. No. 147780 Lacson v. Perez

G.R. No. 159085 Sanlakas v. Executive Secretary

G.R. No. 79173 Abadilla v. Ramos

G.R. No. 83177 Kapunan v. De Villa

G.R. No. 84076 Romero v. Chief of Staff

G.R. No. 84581-82 Roque v. De Villa

G.R. No. 92163 Enrile v. Salazar, G.R. No. 92164

Panlilio v. De Leon

G.R. No. 93177 Comendador et al. v. De Villa,

G.R. No. 95020 Camua et al. v. Asuncion,

G.R. No. 97454

Senator Benigno Aquino Jr.

Military Commission No. 34: jurisdiction of military tribunal over civilians 1987

Task Force Makabansa: liability of military superiors for the acts of their 1988 subordinates

Proclamation No. 38 and General Order No. 1: declaration of state of

rebellion in the National Capital Region and order to suppress it by

military and police as a response to the violent protests after the arrest of the former President Joseph Estrada

Proclamation No. 427 and General Order No. 4: declaration of state of rebellion and its suppression, "Oakwood Mutiny"

Petition for habeas corpus: one of the leaders of the "Black Saturday Mutiny" Articles of War and P.D. No. 77, as amended by P.D. No. 911: officers participating in the August 1987 coup d'état

Court martial proceedings vs. officers involved in the August 1987 coup d'état

Petitions for writ of habeas corpus: arrest without warrant of individuals charged with subversion

Complexing of rebellion with other common crimes vs. Senator Juan Ponce Enrile

Articles of War, creation of General Court Martial: right to peremptory

challenge vs. officers of the armed forces 
APPENDIX C. (COH

Case number and classification

Locus standing:

concerned citizens, taxpayers, voters

G.R. No. 138570 Bayan v. Executive Secretary

G.R. No. 141284 IBP v. Zamora

$\mathrm{x}$

G.R. No. 151445 Lim v. Executive Secretary G.R. No. 176051 Salonga et al. v. Smith et al.

G.R. No. 169838 Bayan v. Ermita

G.R. No. 171396 David v. Arroyo

G.R. No. 178552 Southern Hemisphere Engagement Network v. Anti-Terrorism Council et al.

G.R. No. 80508 Guazon v. De Villa

G.R. No. 83988 Valmonte v. De Villa

G.R. Nos. 172070-72 Ladlad v. Velasco

G.R. No. 127685 Ople v. Torres

G.R. No. 168338 Chavez v. Gonzalez,

G.R. No. 170516 Akbayan v. Aquino

G.R. No. 74930 Valmonte v. Belmonte

G.R. No. 82585, G.R. No. 82827, G.R. No. 83979

\section{Case description}

YEAR

Constitutionality of the RP-US Visiting Forces Agreement (VFA)

Deployment of marines to assist the Philippine National Police in law enforcement

Constitutionality of the Balikatan 02-01 RP-US joint military exercises Constitutionality of the RP-US VFA: custody of US armed forces personnel convicted of rape

Calibrated Preemptive Response and Batas Pambansa No. 880: dispersal of unlawful mass actions, "no permit, no rally" policy

Constitutionality of PP 1017 and General Order No. 5: President Arroyo declaration of state of national emergency and order to the armed forces to maintain law and order

Constitutionality of RA 9372 or the Human Security Act of 2007

2000

2000

2002

2009

2006

2006

2010

“Areal Target Zonings" or "Saturation Drives": human rights violations 1990

Constitutionality of checkpoints: search of people's vehicles without a 1989

search warrant

Rebellion charges vs. six party-list representatives, including Rep. Crispin 2007

Beltran who was arrested without warrant

Constitutionality of AO 308: National Computerized Identification

1998

Reference System

Suspension of broadcasting licence: airing wiretapped conversations

2008

implicating President Arroyo of electoral fraud

Doctrine of executive privilege and public disclosure of documents related 2008

to the Japan-Philippines Economic Partnership Agreement

Access to records: Batasang Pambansa members from the political parties 1989

of UNIDO and PDP-Laban

President's privilege of immunity from suit 
II. Legitimacy of presidential succession and executive term limits

G.R. No. 146738 Estrada v. Arroyo, G.R. No 146710-15 Estrada v. Desierto

G.R. No. 73748 Lawyers League for a Better Philippines, etc. v. President Corazon C. Aquino et al.

G.R. No. 127325 Santiago et al. v. Comelec

G.R. No. 140835 Gonzales v. Narvasa

Legitimacy of the Arroyo government

Legitimacy of the Corazon Aquino government

G.R. No. 174153 Lambino v. Comelec

Petition to lift term limits of elective officials through a people's initiative E0 43: creation of the "Preparatory Commission on Constitutional 1997 Reform"

Commission on Election (Comelec) decision: plebiscite authorizing 2006 a people's initiative as instrument for charter change

III. Elections, appointments, and political configuration

G.R. No. 100318 Osmena v. Comelec

Constitutionality of RA 7056: synchronized local and national elections in 1992

G.R. No. 159139 Information Technology

Foundation of the Philippines v. Commission on Elections

G.R. No. 161434 Tecson v. Comelec

G.R. No. 188456 Roque v. Comelec

Contract awarded by the Comelec for the automation of the 2004 elections

Disqualification of Fernando Poe, Jr. in the 2004 presidential race

RA 9369 or the Poll Automation Act: P7.2 billion poll automation contract 2009 between the Commission on Elections and Smartmatic Corp.-Total Information Management Inc.

G.R. No. 189698 Quinto v. Comelec

RA 9369, Sec. 66 of the Omnibus Election Code \& Sec. 4(a) of

COMELEC Resolution No. 8678: public appointive officials considered resigned after filing their certificate of candidacy

P.E.T. Case No. 001 Santiago v. Ramos

P.E.T. Case No. 003 Legarda v. De Castro

Electoral protest: poll victory of Fidel Ramos in the presidential election by 1996 his rival Miriam Defensor Santiago

Electoral protest: proclamation of Noli De Castro as newly elected 2005

Vice-President of the Philippines by Loren Legarda

G.R. No. 100113 Cayetano v. Monsod 


\section{Case number and classification}

G.R. No. 134171 Executive Secretary v. Gordon

G.R. No. 149036 Matibag v. Benipayo et al.

G.R. No. 191002 De Castro v. JBC

G.R. No. 86439 Bautista v. Salonga

G.R. No. 111511 Garcia v. Comelec

G.R. No. 134577 Santiago v. Guingona

G.R. No. 137718 Malonzo v. Zamora

G.R. No. 149453 People of the Philippines v. Lacson

G.R. No. 179271 Banat v. Comelec

G.R. No. 86344 Daza v. Victorino

G.R. No. 86649 Coseteng v. Mitra

G.R. No. 97710 Bondoc v. Pineda et al.

G.R. No. 99031 Llamas v. Executive Secretary

G.R. No. 164978 Pimentel v. Ermita

G.R. No. 180050 Navarro v. Sec. Ermita

G.R. No. 183591 The Province of Cotobato v. The

Gov't of the Republic of the Philippines

G.R. No. 189793 Aquino v. Comelec

\section{Locus standing:}

concerned citizens,

taxpayers, voters

\section{Case description}

YEAR

Recall and withdrawal of appointment of Richard Gordon, a Ramos appointee 1998

as Chair of the Subic Bay Metropolitan Authority under Estrada

Ad interim appointments in the Commission on Elections including the 2002 position of the Chair (Sec. 1 Art. IX of the Constitution)

Appointment of Renato Corona as Supreme Court Chief Justice in the light 2010 of a constitutional ban on midnight appointments

Appointment of the Chairman of the Commission on Elections, despite 1989 rejection by the Commission on Appointments

Constitutionality of Sec. 70 of the Local Government Code of 1991: 1993

Preparatory Recall Assembly

Determination of the legitimate Senate Minority Leader

1998

President's suspension of a local government official (Mayor of Caloocan 1999 City)

Two-year time bar for the revival of cases concerning Senator Panfilo

2003

Lacson

Constitutionality of the 2\% threshold for party list group representation in 2009

Congress

Composition of the Commission on Appointments 1989

Reorganization of the Commission of Appointments 1990

Removal from the House of Representatives Electoral Tribunal 1991

President's power to grant executive clemency to the Governor of Tarlac 1991

Ad interim appointments 2005

Constitutionality of RA 9335 creating the province of Dinagat Islands 2010

Constitutionality of the Memorandum of Agreement on Ancestral Domain 2008

Constitutionality of RA 9716 creating an additional congressional district 2010 for Camarines Sur (Arroyo's son later ran under the new district) 
G.R. No. 73155 Tan v. Comelec

G.R. No. 79956 Cordillera Broad Coalition v. Commission on Audit

G.R. No. 89651 Abbas v. Comelec

G.R. No. 96754 Chiongbian v. Orbos

IV. Priority projects, economic programmes,

budget, and tax

G.R. No. 111230 Garcia v. Comelec

G.R. No. 112399 Bagatsing v. Committee on Privatization, Philippine National Oil Company

G.R. No. 113375 Kilosbayan Inc. v. Guingona (5 May 5 1994)

G.R. No. 114222 Tatad v. Garcia

G.R. No. 115781 Kilosbayan v. Executive Secretary (25 August 1994)

G.R. No. 118295 Tanada et al. v. Angara et al.

G.R. No. 118910 Kilosbayan v. Morato

G.R. No. 124360 Tatad v. Secretary of the Department of Energy

G.R. No. 127882 La Bugal B'laan Tribal Association, Inc. v. Victor Ramos

G.R. No. 127882 La Bugal B'laan Tribal Association, Inc. v. Victor Ramos

G.R. No. 133250 Chavez v. Amari

Constitutionality of Batas Pambansa Blg. 885 creating a new province in the island of Negros

Constitutionality of E0 No. 220 creating the Cordillera Administrative Region

Constitutionality RA 6743 creating an autonomous region in Muslim Mindanao 1989

Constitutionality of RA 6743: relegation of a legislative function to the President 1995

Pambayang Kapasyahan Blg. 10, Serye 1993: inclusion of Morong, Bataan 1994 as part of the Subic Special Economic Zone

Privatization of Petron, a state-owned oil company

Violation of RA 1169: Contract of Lease between the Philippine Charity Sweepstakes Office (PCSO) and the Philippine Gaming Management Corp. (PGMC)

Build-Lease-and-Transfer Agreement concerning the EDSA Light Rail Transit III

Constitutionality of the Expanded Value Added Tax (EVAT) Law

Constitutionality of the "Agreement Establishing the World Trade

Organization"

Petition to nullify the new contract between PCSO and PGMC

Constitutionality of RA 8180, or the Oil Deregulation Act and EO E0 392: 1997 full deregulation of the downstream oil industry

Constitutionality of RA 7942 or The Mining Act of 1995, Implementing 2004 Rules and Regulation, and the Financial Technical Assistance Agreement (FTAA) with Western Mining Corp

Motion for consideration re. earlier SC ruling declaring some provisions in the RA 7942 as unconstitutional

Joint venture agreement between the Public Estates Authority (PEA) and 2002 the Amari Coastal Bay Development Corporation: land transfer of 77.34 hectares of the Freedom Islands and 290.156 hectares of "still submerged areas of Manila Bay" 


\section{Case number and classification}

\section{Locus standing: \\ concerned citizens, \\ taxpayers, voters}

G.R. No. 133250 Chavez v. PEA-AMARI

G.R. No. 138298 Del Mar v. PAGCOR

G.R. No. 155001 Agan v. Piatco

G.R. No. 166429 Republic of the Philippines $v$. Gingoyon

G.R. No. 168056 Abakada Guro Party List Officer Samson Alcantara v. Executive Secretary

G.R. No. 67752 National Economic Protectionism Association v. Ongpin

G.R. No. 78742 Secretary of Agrarian Reform $v$. Association of Small Landowners in the Philippines

G.R. No. 88265 Del Rosario et al. v. Bengzon

G.R. No. 88637 Garcia v. BOI

G.R. No. 92013 Laurel v. Garcia, G.R. No. 92047

Ojeda v. Executive Secretary

G.R. No. 94374 PLDT v. ETPI

G.R. No. L-68474 Nuclear Free Phil. Coalition v. Napocor, G.R. No. 70632

Case description

YEAR

PEA-AMARI motion for reconsideration of an earlier SC ruling

2003

Operation, maintenance, or management of jai-alai games by PAGCOR, 2000

Belle Jai-Alai Corporation, and Filipinas Gaming Entertainment

Totalizator Corporation

Contract for construction, operation, and maintenance of the Ninoy

2003

Aquino International Airport (NAIA) Terminal III between the government and the Philippine International Air Terminals Co. (PIATCO)

Lower court ruling: determination of just compensation in the NAIA III project to PIATCO

Constitutionality of RA 9337 or the VAT Reform Act

PD No. 1789 or The Omnibus Election or Investment Code, the 1981 Investment Priorities Plan, Executive Order No. 676, PD No. 1892: increase in foreign equity participation in some areas of investment

Constitutionality of RA No. 6657, or the Comprehensive Agrarian Reform Law, P.D No. 27, Proc. No. 131, E.O. Nos. 228 and 229: landowner rights of retention

Constitutionality of provisions in the Generics Act of 1988 and implementing AO 62

Transfer of the Bataan Petrochemical Corp. from Bataan to Batangas

Sale of Roponggi property in Japan through an executive order without legislative approval

National Telecommunications Commission decision: granted ETPI the authority to operate an International Digital Gateway Facility in Metro Manila

PAEC Licensing Proceedings No. 1-77: safety and operation of the Philippine nuclear power plant 
G.R. No. 119322 Commissioner of Internal Revenue v. Court of Appeals

G.R. No. 119322 Commissioner of Internal

Revenue v. Court of Appeals

G.R. No. 127255 Arroyo v. De Venecia

G.R. No. 88291 Maceda v. Macaraig

G.R. No. 115781 Kilosbayan v. the Executive Secretary

G.R. No. 113105 Philippine Constitution

Association v. Enriquez

G.R. No. 132988 Pimentel v. Aguirre

G.R. No. 71977 Demetria v. Alba

G.R. No. 94571 Guingona v. Carague

G.R. No. 131457 Fortich v. Corona

G.R. No. 93661 Sharp International Marketing v. Court of Appeals

G.R. No. L-30240 Republic of the Phils. v. Judge De Los Angeles

V. Corruption

G.R No. 128054 Kilosbayan Inc. v. Comelec

G.R. No. 148468 Serapio v. Sandiganbayan G.R. No. 148560 Estrada v. Sandiganbayan

G.R. No. 148571 US v. Purganan

G.R. No. 148965 Jose “Jinggoy” Estrada v. Sandiganbayan

G.R. No. 106718 Araneta v. Sandiganbayan
Tax case vs. Fortune Tobacco Corp., a firm owned by Lucio Tan, a

Marcos ally

Motion for the inhibition of an SC justice in a tax evasion case for his

ties to the respondent

Constitutionality of RA No. 8240: imposition of sin taxes

1997

Exemption of National Power Corporation from taxes

Motion for reconsideration: SC ruling on constitutionality of RA 7716 or 1995 the EVAT Law

General Appropriations Act of 1994: president's veto powers on some 1994 budgetary provisions

AO 372 and 43: order to reduce local government unit's budget and withholding of Internal Revenue Allocation

Constitutionality of PD 1177: discretionary reallocation of funds to any programme, project, activity

Constitutionality of RA 4860: automatic appropriation of debt service 1991

"Win-Win Resolution," Office of the President: conversion of 44 hectares 1998 of agricultural land to an agro-industrial area

Sale of 1,887 hectares of land (Garchitorena estate) to the government under the Comprehensive Agrarian Reform Program (CARP)

Expansion of Hacienda Calatagan that include areas belonging to public domain

Commission on Elections decision: use of P76 million from the Countrywide Development Fund for electioneering purposes

Sandiganbayan decision: plunder charges against Serapio, an Estrada ally 2003

Constitutionality of RA 7080 (as amended by RA 7659) or the Plunder Law

Lower court ruling: allowed Manila Rep. Mark Jimenez, an Estrada ally, to post bail pending possible extradition to the US

Sandiganbayan decision: plunder case concerning Jose “Jinggoy” Estrada, 2002 the son of the former president

Sandiganbayan decision: power of the Presidential Commission on Good Government (PCGG) to conduct investigations on private firms 
Case number and classification

Locus standing:

concerned citizens,

G.R. No. 116941 Antiporda v. Sandiganbayan taxpayers, voters

G.R. No. 152154 Republic of the Philippines v. Sandiganbayan

G.R. No. 74910, G.R. No. 75075, G.R. No. 75094, G.

R. No. 76397 , G.R. No. 79459 , G.R. No. 79520

G.R. No. 75713 Cocofed v. PCGG

G.R. No. 75885 BASECO v. PCGG

G.R. No. 77645 Silverio v. PCGG

G.R. No. 77663 PCGG v. Pena

G.R. No. 79126 Bulletin v. PCGG

G.R. No. 79484 Kant Kwong v. PCGG

G.R. No. 81385 Olaguer et al. v. National Capital Region Regional Trial Court Branch 48

G.R. No. 86926 Virata v. Sandiganbayan

G.R. No. 91925 Cojuangco v. Roxas, G.R. No. 93005 Cojuangco v. Azcuna

G.R. No. 95197 First Philippine Holdings Corp. v. the Sandiganbayan

VI. Other cases of separation of powers

A.M. No. 91-8-225-CA

Case description

YEAR

Sandiganbayan decision: sequestration of assets of Eduardo Cojuangco Jr., 2001

a Marcos crony, in the San Miguel Corporation

Sandiganbayan decision: forfeiture of Marcos's ill-gotten wealth, \$658 2003

million held in escrow at the Philippine National Bank

Sequestration of P33 million shares under the name of Eduardo Cojuangco 1988

in the San Miguel Corp. should be resolved by the Sandiganbayan

Sequestration of properties and assets of Cocofed, a private association that 1989 collects and uses coconut levy funds

EO Nos. 1, 2, 14 and Proclamation No. 3: sequestration and freezing of 1987 assets illegally amassed by Marcos and his cronies

Sequestration of properties of Silverio, a Marcos ally 1987

Jurisdiction of trial courts and Court of Appeals over the PCGG, a quasi- 1988 judicial body

PCGG's voting shares in the Bulletin, a newspaper publication 1988

Sequestration of two garment corporations, with some investors from 1987

Hong Kong, by the PCGG

TRO issued by lower courts against PCGG agents

Sandiganbayan decision: recovery of ill-gotten wealth by Benjamin

Romualdez

PCGG right to vote as shareholders in the San Miguel Corp. and elect the 1991 members of the board of directors

Sandiganbayan approval of the compromise agreement between the FPHC 1991 and the PCGG

Constitutionality of the President's veto power of the 1992 General Appropriations Act which covers the budget of the Supreme Court 
G.R. No. 160261 Francisco v. House of

Representatives

G.R. No. 170165 Gudani v. Senga

G.R. No. 180643 Neri v. Senate

G.R. No. 71908 Romulo v. Yniguez et al.

G.R. No. 89914 Bengzon v. the Senate Blue Ribbon Committee

G.R. No. L-59603 EPZA v. Dulay

G.R. No. 192935 Biraogo v. The Philippine Truth Commission

G.R. No. 88211 Marcos v. Manglapus

G.R. No. 88211 Marcos v. Manglapus
Constitutionality of a second impeachment complaint against Chief Justice 2003 Hilaro Davide, a public official

Presidential directive prohibiting military officials from appearing in

Congressional inquiries without the President's consent

Rights of members of the executive to invoke "executive privilege" during 2008 Senate Committee hearings

Nullification of certain parts of Batasan's Rules of Procedure in 1986 Impeachment Proceedings

Scope of limits of the Senate Blue Ribbon Committee to summon individuals who have pending cases in the Sandiganbayan

Court's right to determine just compensation, constitutionality of section 1987

92 of PD No. 464 and PD No. 794 and section 1 of PD No. 1533

Constitutionality of EO No.1: creation of the Truth Commission to probe 2010 the alleged corrupt deals of former President Arroyo

Executive's power to bar dictator Ferdinand Marcos from returning to the Philippines

Motion for reconsideration filed by the Marcoses, to return to the

Philippines and the remains of the former president 


\section{APPENDIX D: ESTIMATED IDEAL POINTS}

Table D1. Average scores, Aquino term, 1986-92 (including priors)

\begin{tabular}{|c|c|c|c|c|c|}
\hline Ranking & Judge & Ideal point & Std. Dev. & \multicolumn{2}{|c|}{ Appointed by Aquino $=1$} \\
\hline 1 & Gutierrez, Hugo Jr. & -0.51974 & 0.386 & \multicolumn{2}{|c|}{0} \\
\hline 2 & Teehankee, Claudio & 0.13421 & 0.9693 & \multicolumn{2}{|c|}{0} \\
\hline 3 & Melencio Herrera, Ameurfina & 1.1774 & 0.6213 & \multicolumn{2}{|c|}{0} \\
\hline 4 & Sarmiento, Abraham & -2.0 & 0 & \multicolumn{2}{|c|}{1} \\
\hline 5 & Cruz, Isagani & -1.52837 & 0.5017 & \multicolumn{2}{|c|}{1} \\
\hline 6 & Padilla, Teodoro & -1.01287 & 0.3941 & \multicolumn{2}{|c|}{1} \\
\hline 7 & Paras, Edgardo & -0.28395 & 0.3224 & \multicolumn{2}{|c|}{1} \\
\hline 8 & Bidin, Abdulwahid & -0.25486 & 0.3182 & \multicolumn{2}{|c|}{1} \\
\hline 9 & Feliciano, Florentino & -0.13948 & 0.3632 & \multicolumn{2}{|c|}{1} \\
\hline 10 & Feria, Jose & 0.01522 & 1.0032 & \multicolumn{2}{|c|}{1} \\
\hline 11 & Nocon, Rodolfo & 0.02096 & 0.9985 & \multicolumn{2}{|c|}{1} \\
\hline 12 & Yap, Pedro & 0.13405 & 0.97 & \multicolumn{2}{|c|}{1} \\
\hline 13 & Romero Flerida, Ruth & 0.22772 & 0.9364 & \multicolumn{2}{|c|}{1} \\
\hline 14 & Griño Aquino, Carolina & 0.48307 & 0.4146 & \multicolumn{2}{|c|}{1} \\
\hline 15 & Narvasa, Andres & 0.63065 & 0.4531 & \multicolumn{2}{|c|}{1} \\
\hline 16 & Cortes, Irene & 0.67192 & 0.496 & \multicolumn{2}{|c|}{1} \\
\hline 17 & Davide, Hilario Jr. & 0.76111 & 0.7046 & \multicolumn{2}{|c|}{1} \\
\hline 18 & Gancayco, Emilio & 0.81398 & 0.4968 & \multicolumn{2}{|c|}{1} \\
\hline 19 & Regalado, Florenz & 0.81824 & 0.4933 & \multicolumn{2}{|c|}{1} \\
\hline 20 & Medialdea, Leo & 0.8462 & 0.4905 & \multicolumn{2}{|c|}{1} \\
\hline 21 & Fernan, Marcelo & 2 & 0 & \multicolumn{2}{|c|}{1} \\
\hline \multicolumn{6}{|l|}{ NOTES: } \\
\hline \multicolumn{2}{|c|}{ Two-group mean-comparison test } & Mean & Std. Err. & \multicolumn{2}{|c|}{ [95\% conf. interval] } \\
\hline \multirow{3}{*}{\multicolumn{2}{|c|}{$\begin{array}{l}\text { Not appointed by Aquino }=0 \\
\text { Appointed by Aquino }=1 \\
\text { Difference }=\text { mean }(0)-\text { mean }(1) \\
t=0.2435\end{array}$}} & 0.2639567 & 0.1224217 & -1.862408 & 2.390321 \\
\hline & & 0.1224217 & 0.2216808 & -0.3452838 & 0.5901272 \\
\hline & & 0.141535 & 0.5811882 & -1.074102 & 1.360271 \\
\hline
\end{tabular}

Table D2. Average scores, Ramos term, 1992-98 (including priors)

\begin{tabular}{llclc}
\hline Ranking & Judge & Ideal point & Std. Dev. & appointed by Ramos = 1 \\
\hline 1 & Davide, Hilario Jr. & -1.85299 & 0.326 & 0 \\
2 & Cruz, Isagani & -1.38266 & 0.277933 & 0 \\
3 & Feliciano, Florentino & -1.28468 & 0.585833 & 0 \\
4 & Romero Flerida, Ruth & -1.09987 & 0.5672 & 0 \\
5 & Regalado, Florenz & -0.81301 & 0.45885 & 0 \\
6 & Bellosillo, Josue & -0.79573 & 0.446367 & 0 \\
7 & Cortes, Irene & -0.22481 & 1.038067 & 0 \\
8 & Griño Aquino, Carolina & 0.064938 & 0.98055 & 0 \\
9 & Medialdea, Leo & 0.132028 & 0.936 & 0 \\
10 & Nocon, Rodolfo & 0.134668 & 0.93525 & 0 \\
11 & Padilla, Teodoro & 0.47641 & 0.47775 & 0 \\
12 & Bidin, Abdulwahid & 0.919291 & 0.623217 & 0 \\
13 & Narvasa, Andres & 0.989361 & 0.31395 & 0 \\
14 & Torres, Justo Jr. & -0.19045 & 0.957067 & 1 \\
15 & Martinez, Antonio & 0.001675 & 1.001067 & 1 \\
\hline
\end{tabular}


Table D2. (Continued)

\begin{tabular}{llclc}
\hline Ranking & Judge & Ideal point & Std. Dev. & appointed by Ramos = 1 \\
\hline 16 & Quisumbing, Leonardo & 0.004299 & 1.0011 & 1 \\
17 & Hermosisima, Regino Jr. & 0.032053 & 0.554217 & 1 \\
18 & Puno, Reynato & 0.133724 & 0.38285 & 1 \\
19 & Panganiban, Artemio & 0.29738 & 0.929017 & 1 \\
20 & Melo, Jose & 0.620823 & 0.584167 & 1 \\
21 & Quiason, Camilo & 0.924357 & 0.627983 & 1 \\
22 & Mendoza, Vicente & 1.106293 & 0.58575 & 1 \\
23 & Kapunan, Santiago & 1.310765 & 0.348417 & 1 \\
24 & Vitug, Jose & 1.360228 & 0.3552 & 1 \\
25 & Francisco, Ricardo & 1.364099 & 0.741067 & 1
\end{tabular}

NOTES:

Two-group mean-comparison test

Mean

Std. Err.

[95\% conf. interval]

Not appointed by Ramos $=0$

$-0.3643888$

0.2521027

$\begin{array}{ll}-0.913673 & 0.184895\end{array}$

Appointed by Ramos $=1$

0.5804372

0.1739379

0.197602

0.963272

Difference $=\operatorname{mean}(0)-\operatorname{mean}(1)$

$-0.9448259$

0.3113010

$-1.588801-0.300850$

$t=\mathrm{N} 3.0351$

Table D3. Average scores, Estrada term, 1998-2001 (including priors)

\begin{tabular}{llclc}
\hline Ranking & Judge & Ideal point & Std. Dev. & appointed by Estrada = 1 \\
\hline 1 & Romero Flerida, Ruth & -1.36028 & 0.644833 & 0 \\
2 & Vitug, Jose & -1.35376 & 0.416783 & 0 \\
3 & Puno, Reynato & -1.35304 & 0.417133 & 0 \\
4 & Panganiban, Artemio & -0.69822 & 0.6781 & 0 \\
5 & Regalado, Florenz & -0.59674 & 0.824467 & 0 \\
6 & Martinez, Antonio & -0.51773 & 0.776117 & 0 \\
7 & Melo, Jose & -0.40526 & 0.628617 & 0 \\
8 & Davide, Hilario Jr. & -0.33822 & 0.596883 & 0 \\
9 & Bellosillo, Josue & -0.14844 & 0.609033 & 0 \\
10 & Mendoza, Vicente & 0.166383 & 0.528817 & 0 \\
11 & Quisumbing, Leonardo & 0.384675 & 0.5413 & 0 \\
12 & Narvasa, Andres & 0.60435 & 0.80755 & 0 \\
13 & Purisima, Fidel & 0.87689 & 0.575883 & 0 \\
14 & Kapunan, Santiago & 1.798483 & 0.315033 & 0 \\
15 & Gonzaga Reyes, Minerva & -0.16778 & 0.640617 & 1 \\
16 & Buena, Arturo & -0.16765 & 0.639467 & 1 \\
17 & De Leon, Sabino Jr. & 0.314647 & 0.713883 & 1 \\
18 & Pardo, Bernardo & 0.588068 & 0.600533 & 1 \\
19 & Ynares Santiago, Consuelo & 1.570913 & 0.31895 & 1
\end{tabular}

NOTES:

Two-group mean-comparison test

Mean Std. Err. [95\% conf. interval]

\begin{tabular}{lrrrr}
\hline Not appointed by Estrada $=0$ & -0.2100649 & 0.2441925 & -0.737610 & 0.317480 \\
Appointed by Estrada $=1$ & 0.4276396 & 0.3205053 & -0.462225 & 1.317505 \\
Difference $=$ mean $(0)-$ mean $(1)$ & -0.6377045 & 0.4539606 & -1.595478 & 0.320068
\end{tabular}

$t=-1.4048$ 
Table D4. Average scores, Arroyo terms 2001-10 (including priors)

\begin{tabular}{|c|c|c|c|c|}
\hline Ranking & Judge & Ideal point & Std. Dev. & Appointed by Arroyo $=1$ \\
\hline 1 & Ynares Santiago, Consuelo & -1.836 & 0.342217 & 0 \\
\hline 2 & Kapunan, Santiago & -1.70654 & 0.383367 & 0 \\
\hline 3 & Pardo, Bernardo & -1.62063 & 0.39785 & 0 \\
\hline 4 & Sandoval Gutierrez, Angelina & -1.42355 & 0.426417 & 0 \\
\hline 5 & Vitug, Jose & -0.73917 & 0.3092 & 0 \\
\hline 6 & Buena, Arturo & -0.47502 & 0.6112 & 0 \\
\hline 7 & De Leon, Sabino Jr. & -0.40056 & 0.581567 & 0 \\
\hline 8 & Puno, Reynato & -0.3882 & 0.25665 & 0 \\
\hline 9 & Bellosillo, Josue & -0.16698 & 0.469533 & 0 \\
\hline 10 & Panganiban, Artemio & -0.14909 & 0.321217 & 0 \\
\hline 11 & Purisima, Fidel & -0.00504 & 1.002133 & 0 \\
\hline 12 & Quisumbing, Leonardo & 0.400375 & 0.2997 & 0 \\
\hline 13 & Davide, Hilario Jr. & 0.465676 & 0.558233 & 0 \\
\hline 14 & Gonzaga Reyes, Minerva & 0.636526 & 0.734217 & 0 \\
\hline 15 & Melo, Jose & 0.679386 & 0.709233 & 0 \\
\hline 16 & Mendoza, Vicente & 0.749453 & 0.684733 & 0 \\
\hline 17 & Villarama, Martin & -0.53555 & 0.585883 & 1 \\
\hline 18 & Austria Martinez, Alicia & -0.48266 & 0.310283 & 1 \\
\hline 19 & Garcia, Cancio & -0.44148 & 0.657317 & 1 \\
\hline 20 & Callejo, Romeo Sr. & -0.43096 & 0.3781 & 1 \\
\hline 21 & Carpio, Antonio & -0.31325 & 0.317133 & 1 \\
\hline 22 & Azcuna, Adolfo & -0.2911 & 0.313833 & 1 \\
\hline 23 & Carpio Morales, Conchita & -0.27006 & 0.294917 & 1 \\
\hline 24 & Abad, Roberto & -0.08624 & 0.487633 & 1 \\
\hline 25 & Peralta, Diosdado & 0.148172 & 0.43295 & 1 \\
\hline 26 & Perez, Jose & 0.50006 & 0.59185 & 1 \\
\hline 27 & Mendoza, Jose & 0.501369 & 0.5912 & 1 \\
\hline 28 & Reyes, Ruben & 0.601339 & 0.422583 & 1 \\
\hline 29 & del Castillo, Mariano & 0.798585 & 0.50285 & 1 \\
\hline 30 & Chico Nazario, Minita & 0.98159 & 0.408267 & 1 \\
\hline 31 & Tinga, Dante & 1.003344 & 0.427633 & 1 \\
\hline 32 & Brion, Arturo & 1.072208 & 0.461233 & 1 \\
\hline 33 & Velasco, Presbitero Jr. & 1.207078 & 0.442267 & 1 \\
\hline 34 & Bersamin, Lucas & 1.279976 & 0.614633 & 1 \\
\hline 35 & Nachura Antonio, Eduardo & 1.564935 & 0.571267 & 1 \\
\hline 36 & Corona, Renato & 1.711899 & 0.250433 & 1 \\
\hline 37 & Leonardo de Castro, Teresita & 1.795064 & 0.283717 & 1 \\
\hline
\end{tabular}

NOTES:

Two-group mean-comparison test

Mean

$-0.3737102$

0.4911581

$-0.8648683$
Std. Err.

$[95 \%$ conf. interval $]$
Not appointed by Arroyo $=0$

Appointed by Arroyo = 1

Difference $=\operatorname{mean}(0)-\operatorname{mean}(1)$

$t=-3.1423$

$\begin{array}{lrr}0.2202312 & -0.843121 & 0.0957014 \\ 0.172084 & 0.132195 & 0.8501203 \\ 0.275237 & -1.423629 & -0.3061075\end{array}$

